\title{
Ground-based and airborne in-situ measurements of the Eyjafjallajökull volcanic aerosol plume in Switzerland in spring 2010
}

N. Bukowiecki ${ }^{1}$, P. Zieger ${ }^{1}$, E. Weingartner ${ }^{1}$, Z. Jurányi ${ }^{1}$, M. Gysel ${ }^{1}$, B. Neininger ${ }^{2}$, B. Schneider ${ }^{2}$, C. Hueglin ${ }^{3}$, A. Ulrich ${ }^{3}$, A. Wichser ${ }^{3}$, S. Henne ${ }^{3}$, D. Brunner ${ }^{3}$, R. Kaegi ${ }^{4}$, M. Schwikowski ${ }^{5}$, L. Tobler ${ }^{5}$, F. G. Wienhold ${ }^{6}$, I. Engel $^{6}$, B. Buchmann ${ }^{3}$, T. Peter ${ }^{6}$, and U. Baltensperger ${ }^{1}$

${ }^{1}$ Laboratory of Atmospheric Chemistry, Paul Scherrer Institut, Villigen, Switzerland

${ }^{2}$ Metair AG - meteorological airborne observations, Airfield LSZN, Hausen a.A., Switzerland

${ }^{3}$ Empa, Swiss Federal Laboratories for Materials Science and Technology, Dübendorf, Switzerland

${ }^{4}$ Eawag, Swiss Federal Institute of Aquatic Science and Technology, Dübendorf, Switzerland

${ }^{5}$ Laboratory of Radiochemistry and Environmental Chemistry, Paul Scherrer Institut, Villigen, Switzerland

${ }^{6}$ Institute for Atmospheric and Climate Science, Swiss Federal Institute of Technology, Zürich, Switzerland

Received: 1 March 2011 - Published in Atmos. Chem. Phys. Discuss.: 27 April 2011

Revised: 8 September 2011 - Accepted: 21 September 2011 - Published: 4 October 2011

\begin{abstract}
The volcanic aerosol plume resulting from the Eyjafjallajökull eruption in Iceland in April and May 2010 was detected in clear layers above Switzerland during two periods (17-19 April 2010 and 16-19 May 2010). In-situ measurements of the airborne volcanic plume were performed both within ground-based monitoring networks and with a research aircraft up to an altitude of $6000 \mathrm{~m}$ a.s.l. The wide range of aerosol and gas phase parameters studied at the high altitude research station Jungfraujoch ( $3580 \mathrm{~m}$ a.s.l.) allowed for an in-depth characterization of the detected volcanic aerosol. Both the data from the Jungfraujoch and the aircraft vertical profiles showed a consistent volcanic ash mode in the aerosol volume size distribution with a mean optical diameter around $3 \pm 0.3 \mu \mathrm{m}$. These particles were found to have an average chemical composition very similar to the trachyandesite-like composition of rock samples collected near the volcano. Furthermore, chemical processing of volcanic sulfur dioxide into sulfate clearly contributed to the accumulation mode of the aerosol at the Jungfraujoch. The combination of these in-situ data and plume dispersion modeling results showed that a significant portion of the first volcanic aerosol plume reaching Switzerland on 17 April 2010 did not reach the Jungfraujoch directly, but was first dispersed and diluted in the planetary boundary layer. The maximum $\mathrm{PM}_{10}$ mass concentrations at the Jungfrau-
\end{abstract}

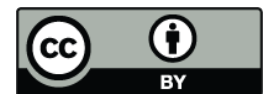

Correspondence to: N. Bukowiecki (nicolas.bukowiecki@psi.ch) joch reached $30 \mu \mathrm{g} \mathrm{m}^{-3}$ and $70 \mu \mathrm{g} \mathrm{m}^{-3}$ (for 10-min mean values) during the April and May episode, respectively. Even low-altitude monitoring stations registered up to $45 \mu \mathrm{g} \mathrm{m}{ }^{-3}$ of volcanic ash related $\mathrm{PM}_{10}$ (Basel, Northwestern Switzerland, 18/19 April 2010). The flights with the research aircraft on 17 April 2010 showed one order of magnitude higher number concentrations over the northern Swiss plateau compared to the Jungfraujoch, and a mass concentration of 320 (200-520) $\mu \mathrm{g} \mathrm{m}^{-3}$ on 18 May 2010 over the northwestern Swiss plateau. The presented data significantly contributed to the time-critical assessment of the local ash layer properties during the initial eruption phase. Furthermore, dispersion models benefited from the detailed information on the volcanic aerosol size distribution and its chemical composition.

\section{Introduction}

The eruption of the volcano Eyjafjallajökull in Iceland in April and May 2010 strongly impaired the flight traffic in large regions of Europe. In central Europe, it caused an almost complete closure of the airspace during several days in mid-April 2010. In Switzerland, the Federal Office of Civil Aviation (FOCA) enacted an airspace closure from Friday, 16 April 2010, 24:00 UTC to Tuesday, 20 April 2010, 09:00 UTC. In the later phase of the Eyjafjallajökull eruption, the airspace was temporarily closed on 8 and 9 May

Published by Copernicus Publications on behalf of the European Geosciences Union. 
2010 in Southern Germany, Northern Italy and Spain, but not in Switzerland. Over the entire time period, a revenue loss of 1.7 billion US Dollars was estimated for the airline industry by the International Air Transport Association (IATA, 2010), which calls for a more detailed analysis of the situation to prevent similar expenses in the future.

The decisions taken by the national regulating agencies in the initial phase of the eruption were mainly based on model predictions by the Volcanic Ash Advisory Centre (VAAC) in London, which is part of an international system set up by the International Civil Aviation Organization (ICAO) called the International Airways Volcano Watch (IAVW). Along with these model predictions, all field measurement data available at this time were used as supplementary information. Since the lead time for actions to be taken in the areas of concern was very short after the initial eruption, the availability of field data was mainly limited to data from existing monitoring networks. In addition, several airborne measurement platforms (Schumann et al., 2011; Rauthe-Schöch et al., 2011; Weber et al., 2010) and remote sensing equipment (Flentje et al., 2010; Gasteiger et al., 2011; Ansmann et al., 2010; Mona et al., 2011) came into operation at a number of European sites. For many of these special measurements a compromise between quick operation and a best possible state of equipment had to be made due to the urgency of the situation. A legally binding threshold for volcanic ash mass concentration did not yet exist in April. On 21 May 2010 the European Union established legal guidelines valid for the entire EU airspace (No Fly Zone: ash concentration level above $4000 \mathrm{\mu g} \mathrm{m}^{-3}$, Enhanced Procedures Zone: ash concentration level between $2000 \mu \mathrm{g} \mathrm{m}^{-3}$ and $4000 \mu \mathrm{g} \mathrm{m}^{-3}$, see EU, 2010).

This paper describes in-situ characterizations of the volcanic aerosol plume detected in Switzerland in April and May 2010. It provides an overview on the physical and chemical characteristics of the detected volcanic aerosol and summarizes the retrieved volcanic ash number and mass concentration values. The experimental data are compared to results from a Lagrangian particle dispersion model similar to the model that is used by the London VAAC. The most comprehensive in-situ data were available from the high-altitude research station Jungfraujoch ( $3580 \mathrm{~m}$ a.s.l). Beside special aerosol filter samples and snow samples collected after the arrival of the first volcanic plume, a large set of physical and chemical aerosol parameters were measured continuously as part of normal operation as GAW monitoring site (Global Atmosphere Watch program by the World Meteorological Organization) and the Swiss Air Quality Monitoring Network (NABEL). In addition to the monitoring networks, a research aircraft was operated during the volcanic plume events in Switzerland (DIMO, Metair AG). The DIMO, flying already on 17 April 2010, was one of the first research aircraft in Europe collecting volcanic aerosol data after the eruption (EUFAR, 2010).

\section{Methods}

\subsection{Measurement sites}

The High Altitude Research Station Jungfraujoch ( $3580 \mathrm{~m}$ a.s.1., $\left.46^{\circ} 32^{\prime} \mathrm{N} 7^{\circ} 59^{\prime} \mathrm{E}\right)$ is located on an exposed anticline in the Swiss Alps. It is operated by the International Foundation High Altitude Research Stations Jungfraujoch and Gornergrat (http://www.hfsjg.ch) and represents a Global Atmosphere Watch station where atmospheric aerosols and gases have been measured for more than $15 \mathrm{yr}$. It is also part of the Swiss Air Quality Monitoring Network, which includes 16 locations in Switzerland distributed throughout the country (http://www.empa.ch/nabel). Table 1 lists the measured variables that are part of the permanent monitoring activities at the Jungfraujoch and were used for the characterization of the volcanic aerosol plume. Due to its altitude and remote location there is no immediate influence from significant anthropogenic pollution sources. The aerosol loading at the Jungfraujoch exhibits a strong seasonal cycle with a maximum in summer and a minimum in winter (Weingartner et al., 1999). Afternoon observations at the Jungfraujoch are influenced by thermally induced injections of more polluted planetary boundary layer (PBL) air during typical fair weather episodes of the warmer seasons (Henne et al., 2004). During most winter days as well as in summer nights, the Jungfraujoch can be regarded as representative of the continental lower free troposphere (Nyeki et al., 1998; Zellweger et al., 2003; Collaud Coen et al., 2011). The area influencing the Jungfraujoch was recently compared with other European background monitoring sites and the site was categorized as "mostly remote" (Henne et al., 2010).

\subsection{Size distribution measurements}

For the continuous size distribution measurements at the Jungfraujoch, an optical particle counter (OPC) and a scanning mobility particle sizer (SMPS) are deployed. Both instruments are connected to a heated total aerosol inlet $\left(25^{\circ} \mathrm{C}\right)$, which besides aerosol particles also allows hydrometeors with $D<40 \mu \mathrm{m}$ to enter and to evaporate, at wind speeds of $20 \mathrm{~m} \mathrm{~s}^{-1}$. The instruments are operated at a laboratory temperature of $25^{\circ} \mathrm{C}$ and a relative humidity $(\mathrm{RH})<15 \%$. The 15-channel OPC (Dust Monitor 1.108, Grimm $\mathrm{GmbH}$ ) was factory calibrated using polystyrene latex spheres (PSLs, refractive index $=1.588$ ) at a laser wavelength of $780 \mathrm{~nm}$, yielding optical diameter $\left(D_{\mathrm{opt}}\right)$ size ranges of $>0.3 \mu \mathrm{m},>0.4 \mu \mathrm{m},>0.5 \mu \mathrm{m},>0.65 \mu \mathrm{m},>0.8 \mu \mathrm{m}$, $>1 \mu \mathrm{m},>1.4 \mu \mathrm{m},>2 \mu \mathrm{m},>3 \mu \mathrm{m},>4 \mu \mathrm{m},>5 \mu \mathrm{m},>7.5 \mu \mathrm{m}$, $>10 \mu \mathrm{m},>15 \mu \mathrm{m}$ and $>20 \mu \mathrm{m}$. The nominal volumetric flow rate of $1.21 \mathrm{~min}^{-1}$ is increased to $1.41 \mathrm{~min}^{-1}$ at the pressure conditions at the Jungfraujoch (640-670 mbar). The flow is checked in regular intervals, and the measured number concentrations are corrected for the increased flow rate. Based 
Table 1. Aerosol and gas phase variables relevant for the detection of volcanic aerosol, measured at the High Alpine Research Station Jungfraujoch, Switzerland (3580 m a.s.1.) within the Global Atmosphere Watch program (GAW) run by the World Meteorological Organization (WMO) and within the Swiss air pollution monitoring network (NABEL). $\mathrm{PM}_{1}, \mathrm{PM}_{10}$ : particulate matter with an aerodynamic diameter smaller than 1 and $10 \mu \mathrm{m}$, respectively. TSP: total suspended particles. CCN: cloud condensation nuclei.

\begin{tabular}{|c|c|c|c|}
\hline Parameter & Employed method or instrument & Time resolution & Network \\
\hline \multicolumn{4}{|l|}{ Particulate matter: } \\
\hline $\mathrm{PM}_{1}$ & Betagauge (Eberline Inc., FH 62-IR) & $10 \mathrm{~min}$ & GAW \\
\hline $\mathrm{PM}_{10}$ & Betagauge (Eberline Inc., FH 62-IR) & $10 \mathrm{~min}$ & GAW, NABEL \\
\hline $\mathrm{PM}_{10}$ filter samples & HiVol (Digitel AG, DHA-80) & daily & NABEL \\
\hline \multicolumn{4}{|l|}{ Major chemical components: } \\
\hline $\mathrm{PM}_{1}$ and TSP filter samples & Sampling with $1 \mathrm{~m}^{3} \mathrm{~h}^{-1}$ & 24 h every 6 th day & GAW \\
\hline \multicolumn{4}{|l|}{ Trace gases: } \\
\hline $\mathrm{SO}_{2}$ & UV fluorescence (Thermo Inc. Model 43C TL) & $10 \mathrm{~min}$ & NABEL \\
\hline \multicolumn{4}{|l|}{ Light absorption coefficients: } \\
\hline 7 defined wavelengths & Aethalometer (Magee Scientific Inc., AE31) & $5 \mathrm{~min}$ & GAW \\
\hline \multicolumn{4}{|l|}{ Light scattering coefficients: } \\
\hline \multicolumn{2}{|l|}{$\begin{array}{l}\text { Total hemispheric scattering } \\
\text { and backscattering coefficient }\end{array}$} & $5 \mathrm{~min}$ & GAW \\
\hline \multicolumn{4}{|l|}{ Aerosol number concentration: } \\
\hline Number concentration & Condensation particle counter (TSI Inc., Model 3772) & $1 \mathrm{~min}$ & GAW \\
\hline \multicolumn{4}{|l|}{ Aerosol size distribution: } \\
\hline $10-350 \mathrm{~nm}$ & Scanning mobility particle sizer (SMPS) & $6 \mathrm{~min}$ & GAW \\
\hline $0.3-20 \mu \mathrm{m}$ & Optical particle counter (Grimm Inc., Model 1.108) & $1 \mathrm{~min}$ & GAW \\
\hline \multicolumn{4}{|l|}{ Size resolved CCN: } \\
\hline $\begin{array}{l}\mathrm{CCN} \text { number concentration spectra } \\
\text { at various supersaturations (SS) }\end{array}$ & $\begin{array}{l}\text { DMA (TSI Inc., Model 3071) + CCNC (DMT Inc.) } \\
\text { with size-resolved (diameter scanning) setup }\end{array}$ & $10 \min \mathrm{SS}^{-1}$ & GAW \\
\hline
\end{tabular}

on the length and geometric design of the inlet line, it is estimated that there is a considerable loss of particles with $D>15 \mu \mathrm{m}$.

As described in detail in Appendix A1, aerosol measurements with an OPC depend on the wavelength-dependent complex refractive index of the sampled aerosol, which determines the scattering response for a particle of a given size and shape. The real part of the refractive index is mainly influenced by the scattering aerosol components, while the imaginary part varies with different contributions from absorbing species. As a result, the measurement of non-PSL aerosols like volcanic ash with a PSL-calibrated OPC will result in a diameter shift of the size distribution due to the different refractive indices. This diameter shift has to be corrected for, because it has a strong influence on the calculation of volume and mass concentrations from the raw number size distributions.

In addition, the aerosol number size distribution is measured for mobility diameters $\left(D_{\text {mob }}\right)$ between 10 and $350 \mathrm{~nm}$ with a SMPS. It consists of a differential mobility analyzer (DMA, TSI Inc., Model 3071) and a condensation particle counter (CPC, TSI Inc., Model 3775). The size distribution is measured every $6 \mathrm{~min}$, with an up-scan time of $300 \mathrm{~s}$. The DMA is operated with $0.31 \mathrm{~min}^{-1}$ sample air flow rate and a closed-loop excess and sheath air setup with a flow rate of $31 \mathrm{~min}^{-1}$. More details are given by Jurányi et al. (2011). The used SMPS type was also intercompared within the EUSAAR project (http://www.eusaar.net) and fulfills the recommendations given by Wiedensohler et al. (2010). The combined SMPS and OPC size distributions shown in this paper refer to $D_{\text {mob }}$ for particles smaller than $350 \mathrm{~nm}$ and to $D_{\text {opt }}$ for larger particles.

\subsection{Deduction of the hygroscopicity parameter $\kappa$}

The cloud condensation nuclei counter (CCNC) was operated downstream of a differential mobility analyzer (DMA). From these size resolved cloud condensation nuclei (CCN) 
measurements and total number concentration measurements (see Table 1 ) the hygroscopicity parameter $\kappa$ (Petters and Kreidenweis, 2007) was derived. The measured CCN concentrations were inverted following the method described by Petters et al. (2009), and the activated fraction distribution $\left(\mathrm{AF}=N_{\mathrm{CCN}} / N_{\mathrm{CN}}\right.$, the cumulative distribution function of the activation diameter) was calculated. The hygroscopicity parameter $\kappa$ was then determined from the median activation diameter and represents an average hygroscopicity of all particles with sizes around the average activation diameter.

\subsection{Chemical and electron-microscopical analysis of air and snow samples}

During the volcanic plume events detected at the Jungfraujoch, different types of aerosol samples were collected on filters (see Table 1). The daily $\mathrm{PM}_{10}$ samples collected with a high-volume sampler on quartz fiber filters (Pallflex Tissuquartz 2500QAT-UP) were analyzed using inductively coupled plasma mass-spectrometry (ICP-MS) and ion chromatography (IC), after a closed microwave digestion using an acid mixture of $\mathrm{HNO}_{3} / \mathrm{H}_{2} \mathrm{O}_{2}$. These filters are commonly used within the NABEL network for the determination of $\mathrm{PM}_{10}$ by gravimetric methods and quantification of selected elements. Hence, also filters from previous time periods (from the NABEL sample archive) were available for comparison with the collected volcanic aerosol. The silica content is not accessible from these filters due to the use of quartz fiber filters for aerosol collection.

In addition, daily TSP and $\mathrm{PM}_{1}$ samples collected on Teflon filters were digested in $\mathrm{HF} / \mathrm{HNO}_{3} / \mathrm{H}_{2} \mathrm{O}_{2}$ and analyzed using ICP-MS and IC. A separate portion (1/8) of the collected TSP filters was also analyzed by scanning electron microscopy (SEM). For improved SEM analysis, TSP was resuspended in ethanol and redeposited on Nucleopore filters by filtration. The prepared samples were analyzed by SEM (NanoSEM 230, FEI Inc.) in low vacuum mode. Elemental analysis was carried out with an energy dispersive X-ray fluorescence (EDX) detector (X-MAX 80, Oxford) attached to the microscope.

Snow samples were collected from two shallow snow pits at the Jungfraujoch on 23 April 2010, after the initial arrival of the volcanic plume. Sampling resolution within the two snow pits was $5 \mathrm{~cm}$, to a maximal depth of $50 \mathrm{~cm}$ and $15 \mathrm{~cm}$, respectively. The ash was clearly visible as gray layer confined to the uppermost $10 \mathrm{~cm}$. Major ions were analyzed by IC. Trace element analysis was done by high-resolution ICPMS after acidification of the samples to $0.2 \mathrm{~mol}$ with ultra pure concentrated nitric acid. Furthermore, snow samples were filtrated to analyze the particles on the filters by SEMEDX.

\subsection{Airborne measurements}

The DIMO research aircraft (Diamond Aircraft HK36 TTCECO, call sign HB-2335) from Metair AG (Switzerland) conducted measurements up to an altitude of $6000 \mathrm{~m}$ a.s.l., at an average travel speed of $180 \mathrm{~km} \mathrm{~h}^{-1}$. Instruments were mounted in underwing pods on both wings. A detailed description of the whole system is given by Neininger et al. (2001). At the time of the eruption of Eyjafjallajökull, the measuring system happened to be configured for a study on $\mathrm{CH}_{4}$ sources in Switzerland. This allowed for a quick deployment of the aircraft after the initial volcanic eruption, however only with a semi-quantitative setup of the aerosol instrumentation in the initial phase of the measurements. Nevertheless, this delivered unique in-situ data about the vertical distribution of the volcanic aerosol, and partly about it's horizontal distribution and temporal change. Since the DIMO is a motor glider and has a piston engine, there was no immediate danger for the plane caused by the volcanic plume in $3000 \mathrm{~km}$ distance from the eruption source. An exceptional flight permission was obtained from the FOCA (the Swiss Federal Office for Civil Aviation) for flights under visual flight rules as from 17 April 2010. Subsequently, DIMO flights were performed on 17, 18 and 19 April 2010 (closed airspace), 29 April 2010 (technical flights, no volcanic plume), 9 May 2010 (open air space, low density plume present) and 18 May 2010 (open air space, distinct plume present).

Two OPCs were used to measure aerosol number concentrations during the flights. The MetOne Model 4903 (Hach Ultra Analytics Inc., USA) counts particles in the $D_{\text {opt }}>$ $0.3 \mu \mathrm{m}$ and $D_{\mathrm{opt}}>0.5 \mu \mathrm{m}$ optical diameter range (PSL calibrated), at $2.31 \mathrm{~min}^{-1}$ flow rate with a time resolution of $1 \mathrm{~s}$. This counter belongs to the core instrumentation of the aircraft and was on board during all the flights. The second OPC was a Grimm Dust Monitor 1.108 (Grimm GmbH) with the identical specifications (laser wavelength $780 \mathrm{~nm}$ ) as the counter used at the Jungfraujoch (see Appendix A1). The instrument logged data every $6 \mathrm{~s}$. In contrast to the MetOne counter, the Grimm 1.108 counter was not ready for in-flight operation during the initial flights into the volcanic plume in mid-April 2010 and was first operational on 29 April 2010. The inlet system for the two optical counters is described in Appendix A2. The true air speed, pressure, the inlet misalignment angle as well as meteorological data are parameters of major importance to assess in-flight particle sampling losses. These parameters were logged at $10 \mathrm{~Hz}$ during the flights.

\subsection{Plume dispersion modeling}

Ash concentrations were simulated with the Lagrangian particle dispersion model FLEXPART (Version 8.1, Stohl et al., 2005) using the volcanic ash source strength and vertical distribution as determined for the Eyjafjallajökull eruption by 
Stohl et al. (2011). The simulation was driven by 3-hourly ECMWF (European Centre for Medium-Range Weather Forecasts) operational analysis and forecast $(T+3 \mathrm{~h})$ fields, with a horizontal resolution of $0.5^{\circ} \times 0.5^{\circ}$ for the European domain and a nested higher resolution domain $\left(0.2^{\circ} \times 0.2^{\circ}\right)$ covering the Alpine area. Since the main focus of this study is on volcanic ash transported for several days in the atmosphere, only a single volcanic ash mode with $3 \mu \mathrm{m}$ mean diameter was considered, which was also the main mode observed at the Jungfraujoch (Sect. 3.1.1). Of the erupted mass in the size range $2.8-28 \mu \mathrm{m}$ as determined by Stohl et al. (2011), $40 \%$ were assumed to be in the $3 \mu \mathrm{m}$ mode. Comparing to the size distribution given in Stohl et al. (2011) this fraction seems to be very large, we however manually tuned this fraction to best match the total mass observations in the coarse mode at the Jungfraujoch, Zugspitze (Germany), and the Swiss NABEL sites. Eight million model particles were released for both eruption episodes (April and May) proportional to the source strength, and followed for nine days. Simulated particles experienced wet and dry deposition during the transport and sedimentation was treated as additional deposition in the PBL. Average concentration fields were stored every two hours with a horizontal resolution of $0.1^{\circ} \times 0.1^{\circ}$ and in vertical layers of $500 \mathrm{~m}$ extent.

\section{Results and discussions}

\subsection{The volcanic plume at the Jungfraujoch}

\subsubsection{Identification of the volcanic plume}

The long-term measurements performed at the Jungfraujoch since 1995 suggest that normally no significant coarse mode aerosols are present with the exception of Saharan dust (Collaud Coen et al., 2004). In April and May 2010 several episodes with coarse mode volume concentrations clearly exceeding the background levels were identified at the Jungfraujoch (Fig. 1a) beside the largely continuous presence of the accumulation mode at $D_{\mathrm{mob}}=0.1-0.4 \mu \mathrm{m}$. Two of these episodes were related to the volcanic plume (1719 April 2010 and 18-19 May 2010). In addition, a distinct Saharan dust event was detected on 8 April 2010 about 11 days before the arrival of the first volcanic plume, with a coarse mode volume concentration comparable to the volcanic aerosol events. These Saharan dust events typically show their maximum of occurrence at the Jungfraujoch in spring. They can be identified based on the wavelength dependent dry measurements of the light scattering coefficient $\sigma_{\mathrm{sp}}$ and the light absorption coefficient $\sigma_{\text {ap }}$ (Collaud Coen et al., 2004). The wavelength dependence of the single scattering albedo $\left(\omega_{0}=\sigma_{\mathrm{sp}} /\left(\sigma_{\mathrm{sp}}+\sigma_{\mathrm{ap}}\right)\right)$ is inversed during Saharan dust events, such that the dry Angström exponent of the single scattering albedo $\left(\alpha_{\omega}\right)$ becomes negative (Fig. 1e, purple line on right axis) in the presence of mineral dust (Col- laud Coen et al., 2004). The reason for this inversion is the increased wavelength dependence of the absorption coefficient for the reddish Saharan dust, as well as the clear dominance of the mineral dust coarse mode during these episodes leading to a lower wavelength dependence of the scattering coefficient. In contrast to Saharan dust, the Ångström exponent remained positive during the two episodes in April and May, when the volcanic plume reached the Jungfraujoch. This indicates the different chemical composition and color of the two aerosol types and reflects the fact that the volcanic plume also contained a distinct accumulation mode, which dominated the measured scattering characteristics (as later explained in Sect. 3.1.5).

The two events related to the volcanic plume were first recognized and characterized by strongly increased concentrations of $\mathrm{PM}_{10}$ and $\mathrm{SO}_{2}$ (Fig. 1b). As it will be discussed in Sect. 3.2.3, the Jungfraujoch only faced the diluted and rather inhomogeneous edge of the volcanic plume in April 2010. During the April event the volcanic plume reached the site for the first time under relatively dry conditions and local winds from South (17 April 2010, 18:00-24:00 UTC+1, ambient $\mathrm{RH}=40-60 \%$ ), indicated by a simultaneous increase in $\mathrm{PM}_{10}$ and $\mathrm{SO}_{2}$ (Fig. 1b, c, d). Subsequently, the local wind direction changed to NW, accompanied by an engulfment of the site in clouds (ambient $\mathrm{RH}=95-100 \%$ ). The change in weather conditions coincided with a drop in $\mathrm{SO}_{2}$, while $\mathrm{PM}_{10}$ stayed constant. The changing levels of $\mathrm{SO}_{2}$ are linked to changing oxidation and neutralization states of the volcano related sulfur, which is discussed in detail in Sect. 3.1.2.

In May 2010 the volcanic plume was first detected at the Jungfraujoch on 16 May 2010 and again later on 18 May 2010 , reaching $\mathrm{PM}_{10}$ and $\mathrm{SO}_{2}$ concentrations clearly exceeding those observed in April. The highest daily mean value for $\mathrm{SO}_{2}$ in May 2010 was in the same order of magnitude as monthly mean values in the 1970ies before measures to reduce the sulfur in the atmosphere have been taken. The ambient relative humidity was close to $100 \%$ during 18 May 2010 and the early morning of 19 May 2010, related to an engulfment of the site in clouds. A final plume was observed in the afternoon of 19 May 2010 under more cloud-free and dry conditions (ambient $\mathrm{RH}=45-55 \%$ ), accompanied by a shift in local wind direction.

The volcanic plumes detected at the Jungfraujoch showed clearly different characteristics in April and May. This most likely reflects the changing eruption characteristics of the volcano as a function of time, as well as changing transport processes (see Sect. 3.1.2). Despite changing conditions the volume distribution indicates an essentially unchanged diameter of the ash particle mode in the volume distributions (Fig. 2), suggesting that the gravitational settling of larger particles as a function of the net distance from the eruption source was a predominant parameter influencing the coarse mode size distribution. Figure 2 shows that the volume size distributions measured during all these time periods with volcanic influence, exhibited a clear bimodality. The volcanic 

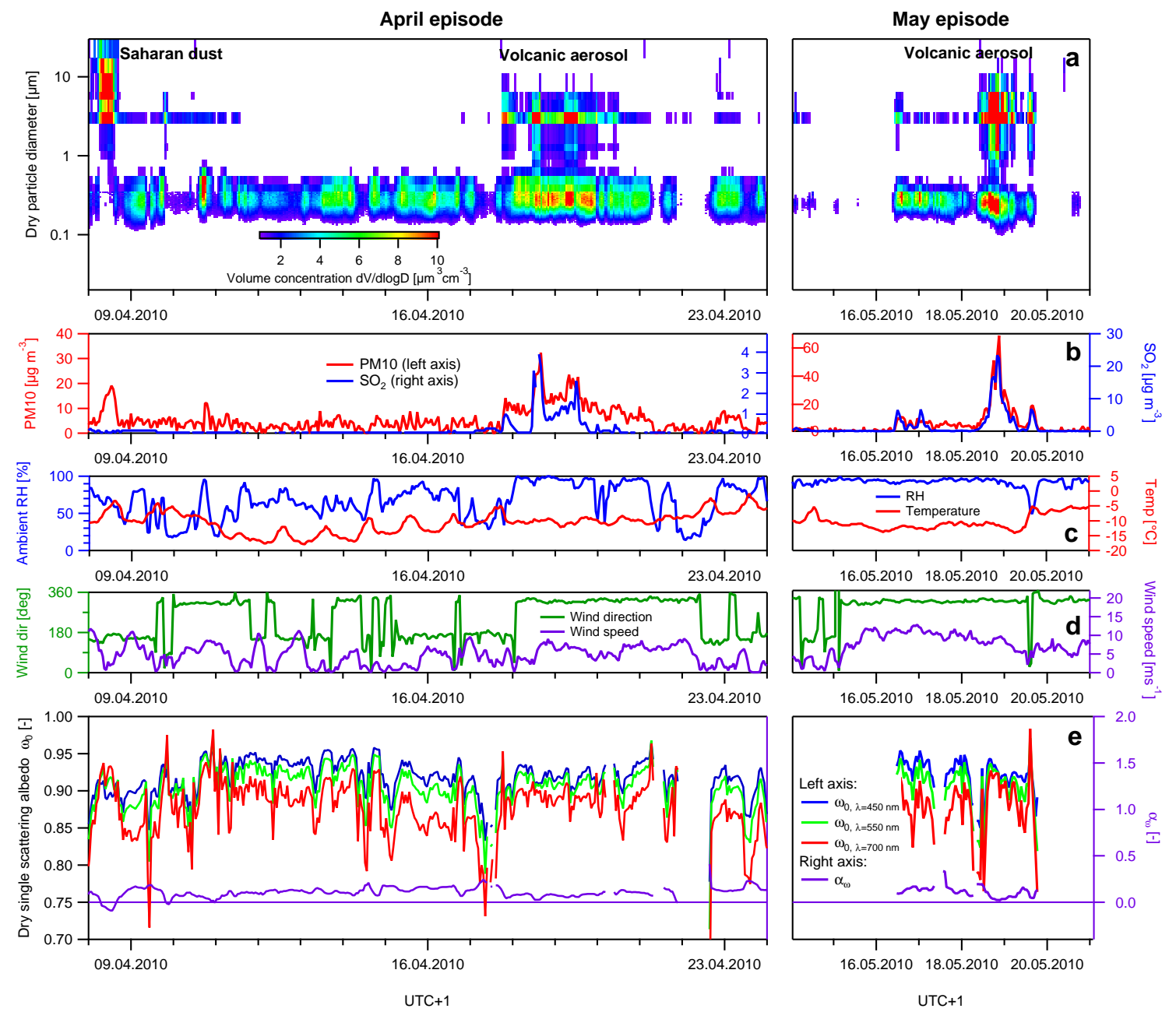

Fig. 1. Temporal evolution of aerosol, gas phase and meteorological parameters measured at the Jungfraujoch around the volcanic aerosol plume and Saharan dust episodes in April 2010 (left panels) and May 2010 (right panels). $\omega_{0}$ : dry single scattering albedo (laboratory conditions). $\alpha_{\omega}$ : Ångström exponent of the dry single scattering albedo. Time is local time (UTC+1 h).

aerosol plume was thus characterized by an accumulation mode in the diameter range $0.1-0.8 \mu \mathrm{m}$ and an ash mode (volcanic ash) with concentrations peaking around $3 \mu \mathrm{m}$. This terminology will be used throughout the rest of this paper.

\subsubsection{Processing of volcanic sulfur dioxide}

The accumulation mode aerosol at the Jungfraujoch during the plume episodes consisted of the normal background aerosol, plus contributions of volcano related aerosol compounds. The observed increases in $\mathrm{SO}_{2}$ (Fig. 3b) coincided with the formation and subsequent growth of nucleation mode particles ( $D=10-50 \mathrm{~nm}$, see Fig. 3c). Likewise, a simultaneous increase was well seen in the hygroscopicity parameter $\kappa$ from 0.15 to 0.4 , at an instrumental supersaturation (SS) of $0.83 \%$ linked to an activation diameter of $50 \mathrm{~nm}$ (see Sect. 2.3). Compared to the average $\kappa$ value of 0.29 at the Jungfraujoch (Jurányi et al., 2011), this increase towards the literature value for sulfuric acid ( $\kappa$ up to 0.9 ) and ammonium sulfate ( $\kappa=0.61$, Petters and Kreidenweis, 2007) indicates a higher inorganic content of the volcanic accumulation mode aerosol. This suggests that the observed nucleation mode particles mainly consisted of nucleated aqueous sulfuric acid particles neutralized by ammonia. The occurrence of these events with increased $\mathrm{SO}_{2}$ followed by nucleation are likely to be linked to the presence of volcanic aerosol in air masses that were not yet dominated by mixing with PBL air or by local cloud formation. Similar nucleation processes were also observed in the volcanic plume over Central France (Boulon et al., 2011).

$\mathrm{PM}_{1}$ and TSP ion concentrations confirmed that most ammonium and sulfate was found in the $\mathrm{PM}_{1}$ fraction (Fig. 4). The absolute increase of these two species during the volcanic episode occurred simultaneously with the increase in 


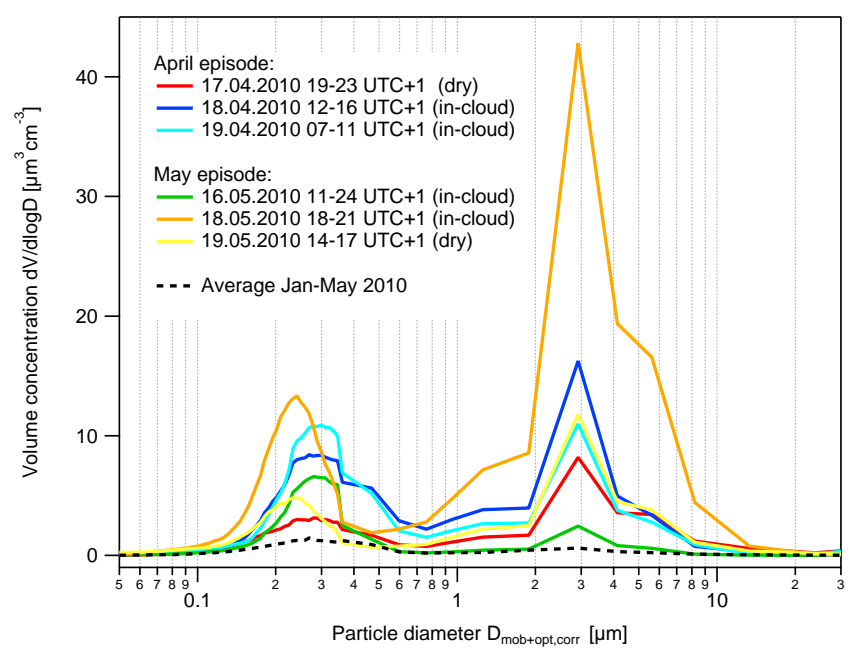

Fig. 2. Volume distributions observed at the Jungfraujoch during time periods with maximal influence by the volcanic aerosol plume. The abscissa represents mobility diameters below $0.5 \mu \mathrm{m}$ (SMPS measurements) and optical diameters above $0.5 \mu \mathrm{m}$ (OPC measurements).

the estimated accumulation mode mass concentration (bottom panel in Fig. 3). These results point to a temporal dominance of the humid air masses (ambient $\mathrm{RH}>90 \%$ ), in which the $\mathrm{SO}_{2}$ to sulfate conversion was completed before the arrival at the Jungfraujoch, either in local clouds or at an earlier stage. A mixing of the volcanic aerosol with PBL air was simulated by the dispersion model results described in Sect. 3.2.2. The significant differences observed in the $\mathrm{SO}_{2} / \mathrm{PM}_{10}$ ratio (0.1-0.2 in April vs. $0.4-0.5$ in May) likely reflects the different proportions of unprocessed and aged volcanic aerosol detected at the Jungfraujoch in April and May, respectively (beside possible differences in eruption characteristics as observed by Heue et al.,, 2011).

\subsubsection{Chemical characterization of volcanic aerosol particles}

An example SEM image taken on a TSP filter (Teflon) collected on 18 April 2010 is shown in Fig. 5. Beside the large number of round-shaped accumulation mode particles, a much smaller number of coarse mode particles in the size range $1-5 \mu \mathrm{m}$ were found (top image). After resuspension of the aerosol and redeposition on Nucleopore filters the coarse mode particles were available for improved SEM-EDX analysis (bottom image). The automated SEM size classification of the particles (3000 particles per sample) showed that the diameter of the particles was below $10 \mu \mathrm{m}$, with a mean geometric diameter around 2-4 $\mu \mathrm{m}$. Figure 6 shows a further SEM image of volcanic ash particles found in snow samples collected on 23 April 2010. Beside particles with a glasslike fractured shape, the SEM images also indicated the presence of particles representing agglomerates of smaller (likely
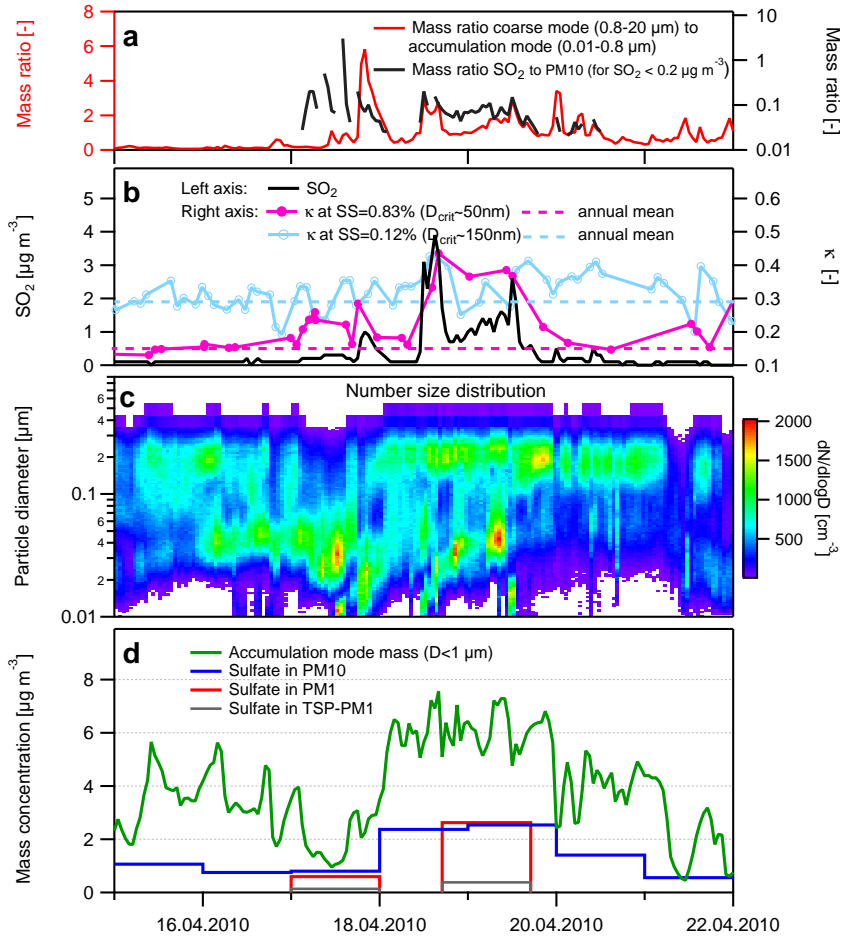

Fig. 3. Temporal evolution of $\mathrm{PM}_{0.8-20} / \mathrm{PM}_{0.8}, \mathrm{SO}_{2} / \mathrm{PM}_{10}$ (a), sulfur dioxide, hygroscopicity parameter $\kappa(\mathbf{b})$, number size distribution (c), sulfate and accumulation mode mass concentration (d), measured at the Jungfraujoch during the volcanic aerosol episode in April 2010. The accumulation mode mass concentration is estimated from the linked SMPS and OPC size distributions and assumes a density of $1.6 \mathrm{~g} \mathrm{~cm}^{-3}$. The indicated $\kappa$ values are derived from the instrumental supersaturation (SS) and the critical activation diameter $\left(D_{\text {crit }}\right)$.
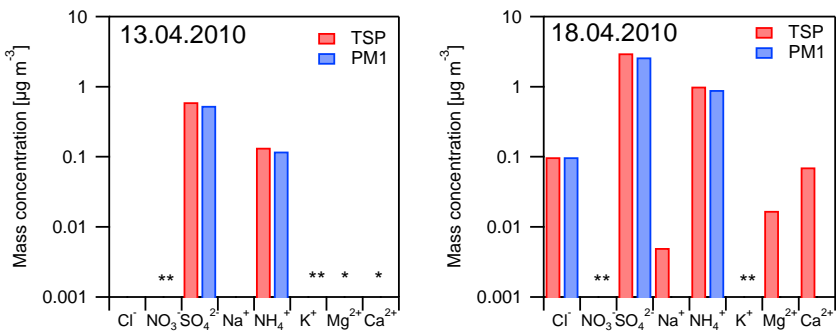

Fig. 4. Ion concentrations in TSP (total suspended particles) and $\mathrm{PM}_{1}$. The filters were collected at the Jungfraujoch on 13 April 2010, 00:00-14 April 2010, 00:00 UTC+1 (background before plume) and 18 April 2010, 17:10-19 April 2010, 17:10 UTC+1 (within volcanic aerosol plume). For nitrate $\left(\mathrm{NO}_{3}^{-}\right)$and potassium (**) and partially also for $\mathrm{Mg}^{2+}$ and $\mathrm{Ca}^{2+}(*)$, no data is available due to high blank values. $\mathrm{SO}_{4}^{2-}$ : sulfate; $\mathrm{NH}_{4}^{+}$: ammonium.

crystalline) particles. Figure 7 shows that both in the air and snow samples, the average chemical composition of the ash particles determined by SEM-EDX is very similar to the 


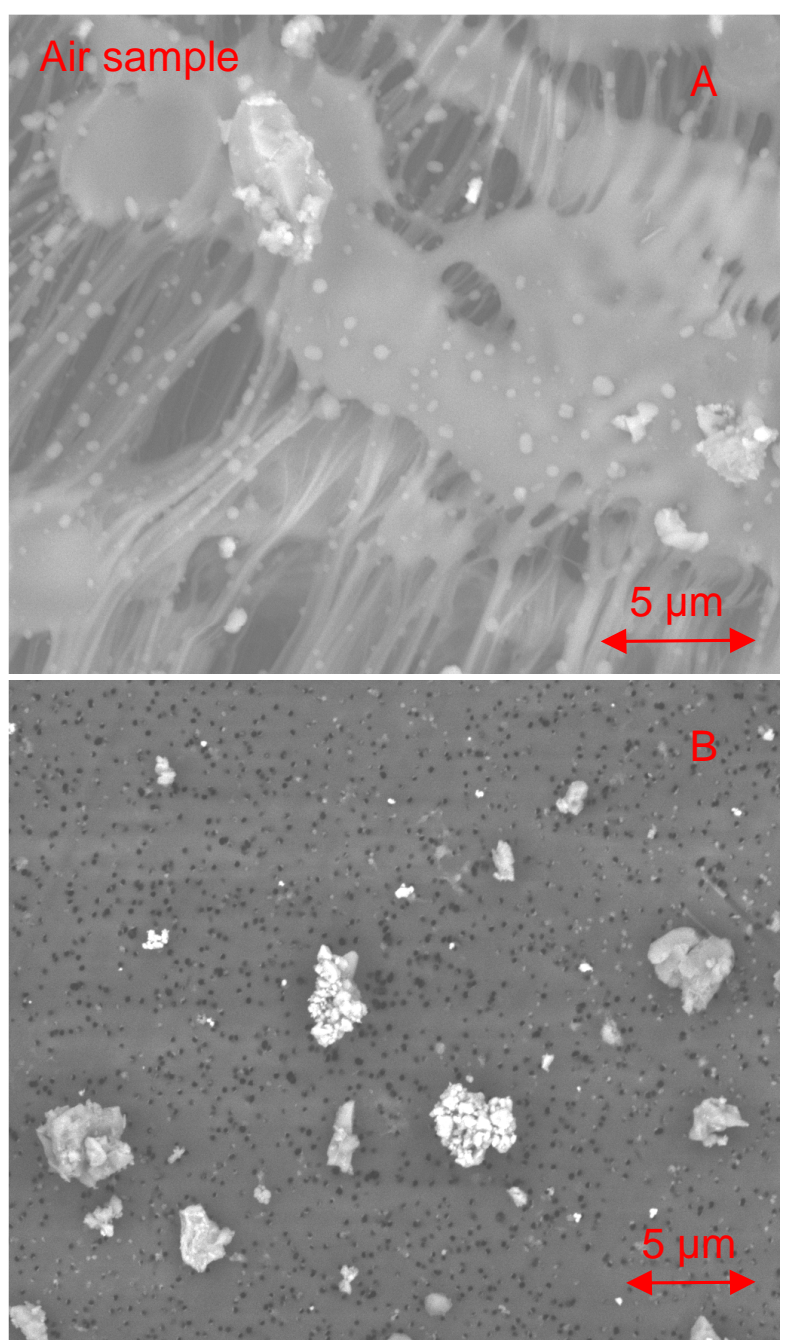

Fig. 5. SEM images of volcanic aerosol collected on a TSP filter at the Jungfraujoch (18 April 2010, 17:10-19 April 2010, 17:10 UTC+1). Top image: original sample. Bottom image: sample after filtration and redeposition on a Nucleopore filter.

one found in a Eyjafjallajökull rock sample collected on 15 April 2010 (Sigmundsson et al., 2010). The observed proportions of $\mathrm{SiO}_{2}, \mathrm{Al}_{2} \mathrm{O}_{3}, \mathrm{FeO}, \mathrm{MnO}, \mathrm{MgO}, \mathrm{CaO}, \mathrm{K}_{2} \mathrm{O}, \mathrm{TiO}_{2}$ and $\mathrm{P}_{2} \mathrm{O}_{5}$ correspond to the compositional pattern of trachyandesite rather than the reference mid-ocean ridge basalt (MORB). The major and trace element concentrations in the collected air and snow samples confirmed the enrichment of the elements related to trachyandesite, and also showed a strong enrichment of rare earth elements $(\mathrm{Ce}, \mathrm{Pr}, \mathrm{Yb}, \mathrm{Nd}$, $\mathrm{Sm})$ which is typical for volcanic ash.

\subsubsection{PM $_{10}$ mass closure}

The information gained by the physical and chemical parameters of the volcanic aerosol was used to obtain a mass closure of the estimated mass distribution with measured

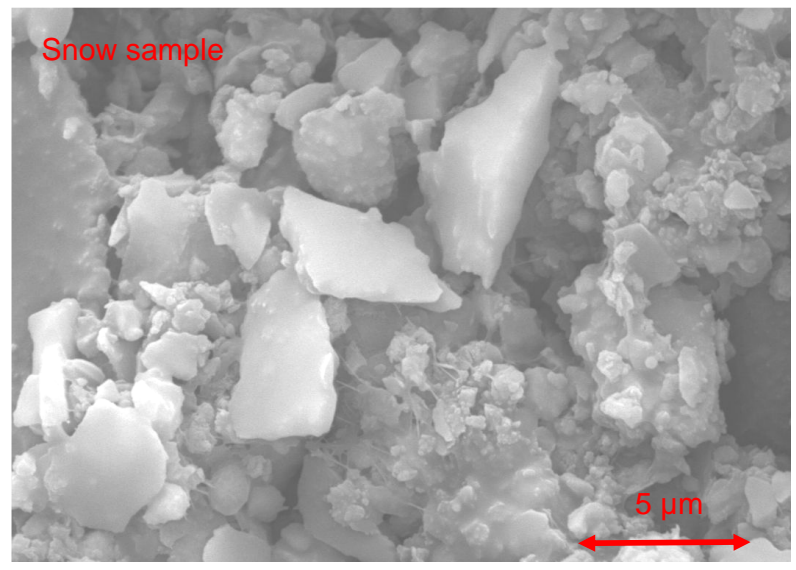

Fig. 6. SEM image of volcanic aerosol collected in a snow sample at the Jungfraujoch after the initial arrival of the volcanic aerosol plume (23 April 2010).

$\mathrm{PM}_{10}$. This closure represents a major quality assurance tool for a reliable correction of the OPC response to volcanic ash particles, as it is described in Appendix A1. Beside the dominant influence of the OPC response on the closure with measured $\mathrm{PM}_{10}$, the selection of the size dependent particle density plays an important role as well. As described in Sect. 3.1.2, the chemical composition of the accumulation mode was not significantly different during the volcanic aerosol plume events compared to the background, except for a moderate but mass relevant increase in ammonium and sulfate (plus minor mass contributions from $\mathrm{Cl}, \mathrm{Mg}$ and $\mathrm{Ca}$ ). Therefore a density of $1.6 \mathrm{~g} \mathrm{~cm}^{-3}$, being a value between the average density for the Jungfraujoch accumulation mode $\left(1.5 \mathrm{~g} \mathrm{~cm}^{-3}\right.$, Cozic et al., 2008) and the density of ammonium sulfate $\left(1.77 \mathrm{~g} \mathrm{~cm}^{-3}\right)$, appeared reasonable for the mass balance calculations. An experimental determination of the density of the coarse mode was not feasible. A value of $2.65 \mathrm{~g} \mathrm{~cm}^{-3}$ was used, which was similar to the density of volcanic ash sampled in Germany (Schumann et al., 2011) and to other literature values (Haynes, 2011). Using the aforementioned densities, the closure between $\mathrm{PM}_{10} \mathrm{cal}-$ culated from the measured size distributions and $\mathrm{PM}_{10}$ measured by beta attenuation was found to have the best agreement assuming a refractive index real part between 1.5 and 1.6 , and an imaginary part between $0.003 \mathrm{i}$ and $0.005 \mathrm{i}$ at the OPC laser wavelength $\lambda=780 \mathrm{~nm}$ (see detailed description in Appendix A1). The closure is shown in Fig. 8 for the volcanic aerosol episodes in April and May 2010. During the Saharan dust event on 8 April 2010 the closure is clearly off, indicating a different refractive index of the coarse material. Very recent unpublished work suggests a somewhat lower lava density $\left(2.4 \mathrm{~g} \mathrm{~cm}^{-3}\right.$, Gudmundsson et al., 2010). Using our methodological approach, an ash density of $2.4 \mathrm{~g} \mathrm{~cm}^{-3}$ would result in an accordingly higher imaginary part (up to $0.01 i)$ for the refractive index of the volcanic ash mode. 

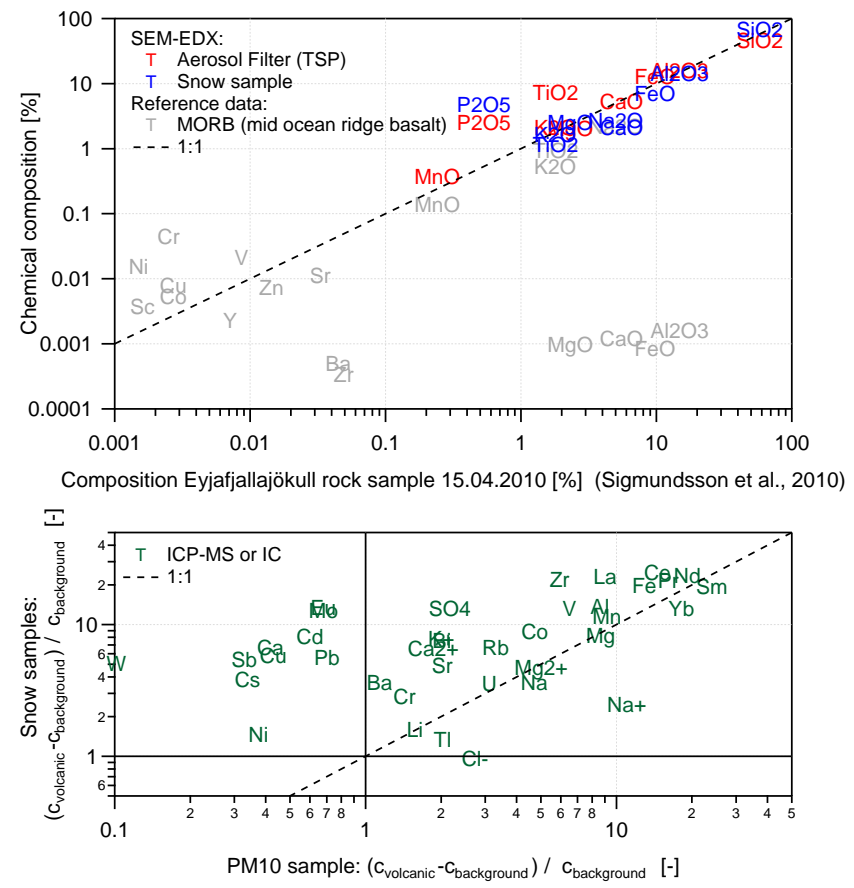

Fig. 7. Top panel: comparison of the ash particle composition (SEM-EDX) in Jungfraujoch air (18 April 2010) and snow (23 April 2010) samples with the composition of a rock sample collected at the Eyjafjallajökull (15 April 2010, Sigmundsson et al., 2010). Additionally, the average composition of the mantle (MORB: Mid Ocean Ridge Basalt) is shown (Blatt et al., 2006). Bottom panel: enrichment factor of ion and trace element concentrations in air and snow samples $\left(c_{\text {volcanic }}\right)$, relative to background concentrations $\left(c_{\text {background }}\right)$ preceding the volcanic aerosol event in April. Ion and trace element concentrations were determined by IC and ICP-MS, respectively. Only elements experimentally determined both in the aerosol and snow samples are shown.

A further independent closure of the volcanic aerosol volume size distributions was achieved by comparing the OPC volume distributions to the volume distributions estimated by SEM, as shown in Fig. 9. The OPC volume distributions are based on corrected optical diameters $D_{\text {opt }}$ using a refractive index of $1.54+0.005 \mathrm{i}(\lambda=780 \mathrm{~nm})$, while the SEM based volume distributions were calculated from the image projection diameter determined for 3000 individual ash particles (assuming spheres). The SEM based distributions only include the coarse mode ash particles, because the accumulation mode particles entered the filter pores during filtration and thus were not accessible to SEM analysis (Sect. 2.4). Considering the complete methodological independence of the two volume distributions and the uncertainties for both methods, there is a good agreement both in terms of the absolute volume concentrations and the mean diameter of the volume distribution coarse mode.

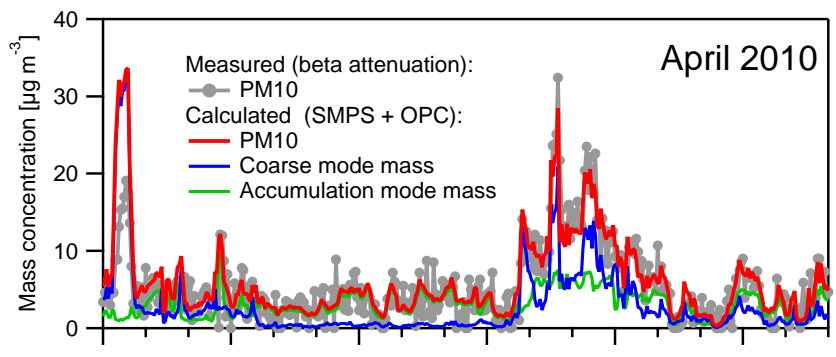

$\begin{array}{llllll}08.04 .2010 & 11.04 .2010 & 14.04 .2010 & 17.04 .2010 & 20.04 .2010 & 23.04 .2010\end{array}$

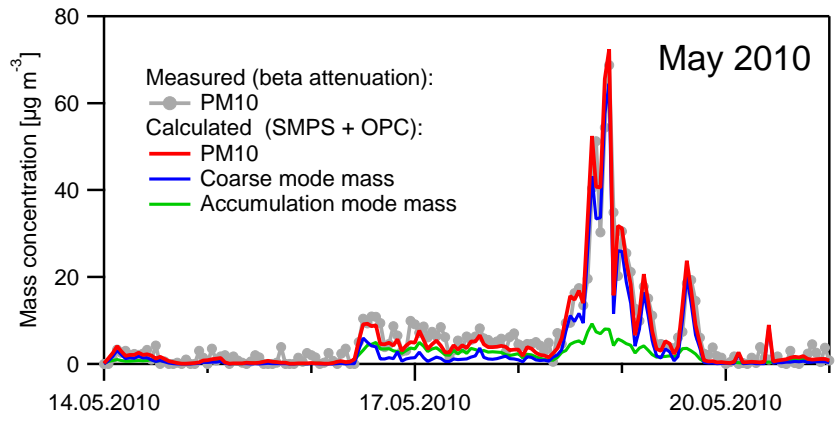

Fig. 8. Closure between measured $\mathrm{PM}_{10}$ and $\mathrm{PM}_{10}$ estimated from the measured number size distributions ( $10 \mathrm{~nm}$ to $20 \mu \mathrm{m}$, measured by SMPS and OPC). A refractive index of $1.54+0.005 \mathrm{i}$ $(\lambda=780 \mathrm{~nm})$ was used to correct the OPC volume distributions, which subsequently were integrated (together with the SMPS distributions) to $\mathrm{PM}_{10}$ mass concentrations assuming densities of $1.6 \mathrm{~g} \mathrm{~cm}^{-3}$ for the accumulation mode (optical diameter $<0.8 \mu \mathrm{m}$ ) and $2.65 \mathrm{~g} \mathrm{~cm}^{-3}$ for the coarse mode (optical diameter $>0.8 \mu \mathrm{m}$ ), respectively. The uncertainty in the beta attenuation measurement is $\pm 1.4 \mu \mathrm{g} \mathrm{m}^{-3}$.

\subsubsection{Refractive index of the volcanic aerosol}

Compared to other refractive index estimates for the volcanic ash (Schumann et al., 2011), the estimated imaginary part of $0.003 \mathrm{i}$ to $0.005 \mathrm{i}$ for the coarse mode ash particles at the Jungfraujoch is slightly higher, indicating the presence of a significant portion of absorbing species within the volcanic ash coarse mode. This seems plausible, considering the dark color of the ash collected on the aerosol and snow samples. In addition, the complex refractive index for the total aerosol (coarse plus accumulation mode) was retrieved via an inversion of the dry scattering and absorption coefficients and the measured and corrected size distribution (SMPS and OPC), using Mie theory (Zieger et al., 2010). The calculations were performed at the specific scattering angles of the nephelometer $\left(7-170^{\circ}\right)$, to avoid the truncation error correction. The angular nephelometer illumination sensitivity (Anderson et al., 1996) was also accounted for in the Mie code. The results for the two volcanic aerosol periods can be seen in Fig. 10. The shown refractive indices have to be interpreted as a mean value for the entire size distribution and are strongly dominated by the accumulation mode. This dominance becomes apparent in the imaginary part, where the rather stable value 

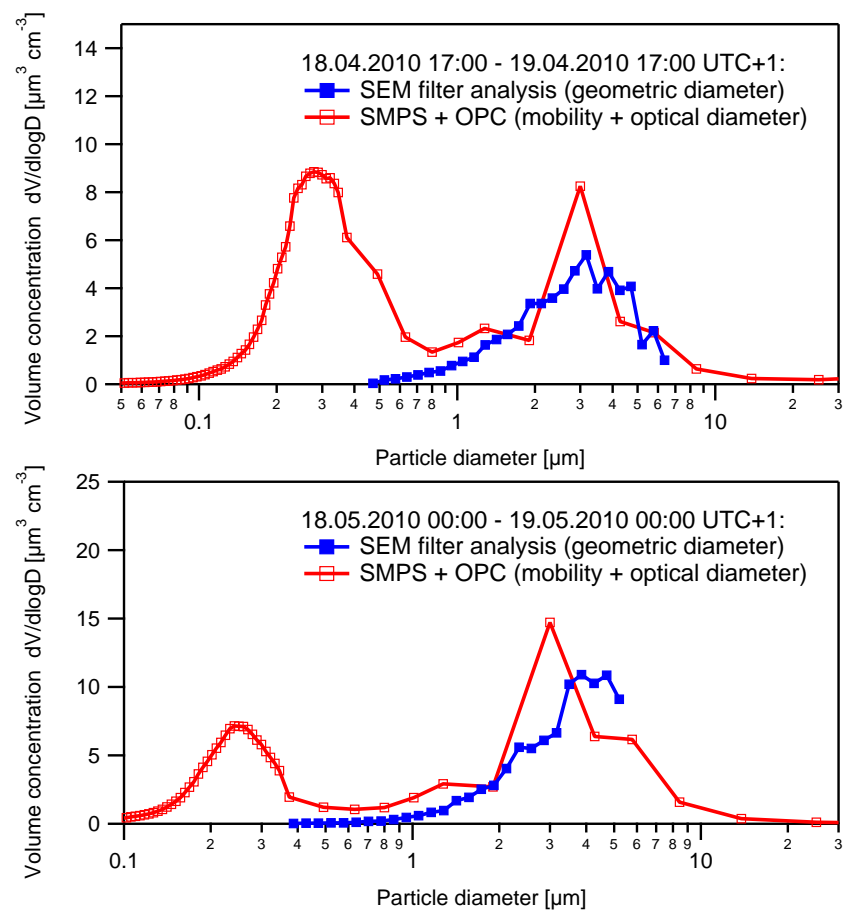

Fig. 9. Closure between the volume distribution measured by SMPS and OPC and the volume distribution estimated by SEM analysis of 3000 ash particles. A refractive index of $1.54+0.005 \mathrm{i}(\lambda=780 \mathrm{~nm})$ was used to correct the OPC volume distributions. The accumulation mode particles were not accessible for SEM analysis (see text). The uncertainties of each of the methods was in the range of the differences between the shown distributions.

of about $0.02 \mathrm{i}$ (average over all wavelengths) measured during the periods dominated by volcanic aerosol is much higher than the values estimated for the ash mode only. The clear decrease of the imaginary part during the volcanic aerosol plume indicates the higher relative contribution of transparent accumulation mode particles. In contrast, the real part shows no significant change and illustrates that the scattering characteristics of the volcanic accumulation mode showed similar scattering characteristics like the normal background aerosol. These results also explain the different behavior of the dry Ångström exponent of the single scattering albedo $\left(\alpha_{\omega}\right)$ during the volcanic plume events (Fig. 1) in contrast to Saharan dust.

\subsection{Spatial distribution of volcanic aerosol over Switzerland}

\subsubsection{Plume tracking via aircraft measurements}

While the stationary measurements at the Jungfraujoch only captured the edge of the volcanic plume (Sect. 3.2.3), the aircraft measurements were useful to investigate the spatial plume inhomogeneity. Figure 11 shows the altitude profile of the number concentration for particle diameters larger than

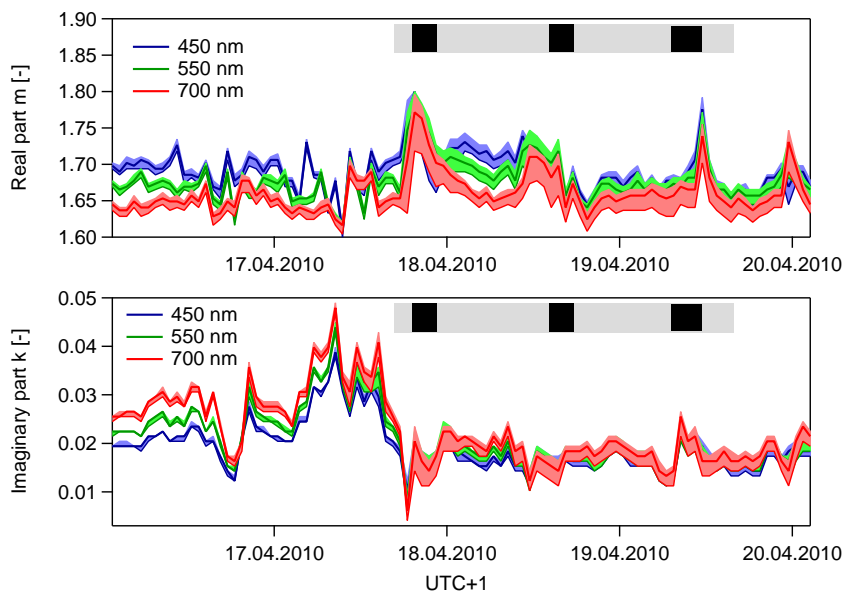

Fig. 10. Mean complex refractive index for the total Jungfraujoch aerosol retrieved from nephelometer, aethalometer and size distribution measurements using Mie theory (assuming a $60 \times 60$ matrix of real and imaginary parts). The shaded areas show the variability if the maximum and minimum values of the corrected Jungfraujoch size distributions are used, see Fig. A4. The horizontal bars mark the presence (gray) and maximal influence (black) of the volcanic aerosol plume.

$D_{\text {opt }}=0.5 \mu \mathrm{m}\left(N_{>0.5}\right)$ measured with the MetOne particle counter, along with the corresponding flight track map. The shown number concentrations were corrected for sampling losses due to anisokinetic sampling and transport losses, but are still associated with an estimated uncertainty larger than $\pm 60 \%$ due to a non-ideal inlet setup, see Appendix A2. During the flights on 17-19 April 2010 the Grimm 1.108 particle counter was not operational, therefore no further size classification was possible. In May, the Grimm 1.108 particle counter was installed in the aircraft and tested on technical flights with an optimized inlet setup (Appendix A2).

The flight on 17 April 2010 showed a distinct ash layer over the Swiss plateau, at an altitude between 2500 and $3000 \mathrm{~m}$ a.s.l. $N_{>0.5}$ reached 80 particles $\mathrm{cm}^{-3}$ within the ash layer, with a maximum of 120 particles $\mathrm{cm}^{-3}$ over Zürich around noon. The crew reported a sulfurous smell in the cockpit. Crossing the altitude of the plume in the late afternoon once again showed clearly decreased ash concentration levels, indicating a strong inhomogeneity of the ash layer or its transport out of the domain. The $N_{>0.5}$ number concentrations of the ash mode observed on the subsequent day (18 April 2010) were clearly lower compared to the values of the day before, indicating that the air masses containing the volcanic aerosol had further subsided. Finally, on 19 April 2010 slight increases of $N_{>0.5}$ over the Swiss plateau and parts of the Alps again indicated the presence of the processed plume at 3500-4500 $\mathrm{m}$ a.s.l. During the second plume event in May, a clear ash layer was again observed over the Swiss plateau on 18 May 2010 at an altitude of $3500 \mathrm{~m}$ a.s.l., which coincides with the altitude of the Jungfraujoch site where the 
plume was clearly detected as well (Sect. 3.1.1). Figure 12 shows the volume distributions measured within the ash layer on 18 May 2010. The maximum $d V / d \log D$ volume concentration of the coarse mode was approximately 5-10 times higher than the corresponding maximum value detected at the Jungfraujoch. This corresponded to an average mass concentration of $320 \mu \mathrm{g} \mathrm{m}^{-3}$ (minimum scenario $200 \mu \mathrm{g} \mathrm{m}^{-3}$, maximum scenario $520 \mu \mathrm{g} \mathrm{m}^{-3}$, based on methodological uncertainties described in Appendix A1), which was estimated from the sampling loss and diameter corrected number size distribution measured by the Grimm 1.108, assuming a density of $2.65 \mathrm{~g} \mathrm{~cm}^{-3}$ for the coarse mode.

The conversion of the measured in-flight number concentrations into mass concentration values was not performed for the April data obtained by the MetOne counter, because the instrument cannot provide any information on the particle size above $0.5 \mu \mathrm{m}$. This is however necessary for a proper calculation of the integrated volume and mass concentration. Together with the large uncertainties inferred from the inflight sampling loss corrections, the deduction of a particle mass concentration from these data would lead to uncertainties too large for a reasonable interpretation of the results.

\subsubsection{Volcanic aerosol related $\mathrm{PM}_{10}$ increases within the planetary boundary layer}

The $\mathrm{PM}_{10}$ and $\mathrm{SO}_{2}$ concentrations measured at the individual stations within the Swiss Air Pollution Monitoring Network helped revealing further locations and time periods with volcanic aerosol impact in April and May. Figure 13 shows that besides the high Alpine site Jungfraujoch, the station in Basel (Northwestern Switzerland) recorded a similar $\mathrm{PM}_{10}$ and $\mathrm{SO}_{2}$ increase during the volcanic aerosol episodes in April (17-19 April 2010), indicating the presence of volcanic aerosol in the planetary boundary layer. During the May 2010 episode (15-19 May 2010), volcanic aerosol was clearly present at two low-altitude sites in Southern Switzerland (Lugano and Magadino, Fig. 13).

To estimate the mass contribution of volcanic ash to total $\mathrm{PM}_{10}$ at the involved stations, titanium dioxide $\left(\mathrm{TiO}_{2}\right)$ was used as suitable source specific tracer for the volcanic aerosol, because $\mathrm{TiO}_{2}$ in $\mathrm{PM}_{10}$ was highly enriched during the volcanic ash episodes. $\mathrm{TiO}_{2}$ in $\mathrm{PM}_{10}$ in Switzerland is predominantly of geogenic origin and concentrations are typically low. Using the background corrected mass concentration of $\mathrm{TiO}_{2}$ in $\mathrm{PM}_{10}$ samples from Jungfraujoch, the $\mathrm{TiO}_{2}$ mass content in the volcanic aerosol arriving at Jungfraujoch was estimated for $18 / 19$ April 2010 to be $1.1 \%$ and $1.0 \%$, respectively. For the May episode, a lower $\mathrm{TiO}_{2}$ mass content in the volcanic aerosol was obtained ( $0.5 \%$ on 18 May 2010). From the $\mathrm{TiO}_{2}$ mass content and the background corrected $\mathrm{TiO}_{2}$ concentration of $495 \mathrm{ng} \mathrm{m}^{-3}$, a volcanic aerosol contribution of $45 \mu \mathrm{g} \mathrm{m}^{-3}$ was estimated for daily $\mathrm{PM}_{10}$ at Basel on 18 April 2010. This corresponded to $90 \%$ of the total $24 \mathrm{~h}$ $\mathrm{PM}_{10}$ value in Basel $\left(51.5 \mu \mathrm{g} \mathrm{m}^{-3}\right)$, a value also supported by the FLEXPART model estimate $\left(50 \mu \mathrm{g} \mathrm{m}^{-3}\right.$, Fig. 15). Similar observations were made in Mulhouse (France) in close distance to Basel (Colette et al., 2010). On 18 May 2010, the volcanic aerosol was transported from the free troposphere into the planetary boundary layer of Southern Switzerland. Based on the estimated $\mathrm{TiO}_{2}$ mass content for that day and the background corrected $\mathrm{TiO}_{2}$ concentrations, it was found that $\mathrm{PM}_{10}$ at Lugano and Magadino was on 18 May 2010 dominated by the volcanic aerosol. The estimated mass concentration of volcanic aerosol in $\mathrm{PM}_{10}$ was $18.8 \mu \mathrm{g} \mathrm{m}^{-3}$ and $18.3 \mu \mathrm{g} \mathrm{m}^{-3}$, respectively, with hourly peak concentrations reaching $70 \mathrm{\mu g} \mathrm{m}^{-3}$. This corresponded to $72 \%$ and $70 \%$ of the 24-h $\mathrm{PM}_{10}$ concentrations at the two sites $\left(26.1 \mu \mathrm{g} \mathrm{m}{ }^{-3}\right.$ and $26.3 \mu \mathrm{g} \mathrm{m}^{-3}$, respectively).

\subsubsection{Joint interpretation of in-situ data and model results}

To obtain a comprehensive picture of the prevailing impact of volcanic aerosol on air quality in Switzerland, the local insitu data presented above are interpreted in the context of the broader spatial distribution of the plume as simulated with the FLEXPART model (Fig. 14 to Fig. 16). Note that these model results show the distribution of the volcanic plume several thousand kilometers downstream of the source and are therefore associated with considerable uncertainty.

In general, the data show that below an altitude of 4000$5000 \mathrm{~m}$ a.s.l. the dispersion and dilution of the plume was highly heterogeneous on a small spatial scale within the Swiss plateau and especially within the Alps, despite the relatively stable weather conditions. These local effects were however not captured by the meteorological input data of the model and thus likely explain the comparatively poor model results obtained for the Jungfraujoch, which was located near the southern border of the plume in April rather than at its center. Accordingly, this likely explains the differences between the dispersion model results and the in-situ data. For example, the FLEXPART simulation did not indicate any advection from the South during the initial plume arrival at the Jungfraujoch on 17 April, as observed by the in-situ measurements (Fig. 1). However, such local flow systems are unlikely to be represented in the employed meteorological fields and the simulations cannot be expected to reproduce such fine scale structures.

Both the in-situ and the model data from 17-19 April 2010 indicate that the air masses containing the distinct plume layer detected by the aircraft on 17 April 2010 (Fig. 14) were subsiding thereafter and underwent local dispersion and dilution in the boundary layer within the following days (Fig. 15). This initial plume layer was also captured by balloon soundings over Zürich (Engel et al., 2010), which showed an estimated ash mass concentration of $80-150 \mu \mathrm{g} \mathrm{m}^{-3}$ at an altitude of $4600 \mathrm{~m}$ a.s.l. on 17 April 2010, 00:48 UTC. A new plume arriving from the North on 18 April 2010 was only detected on the ground in Basel 


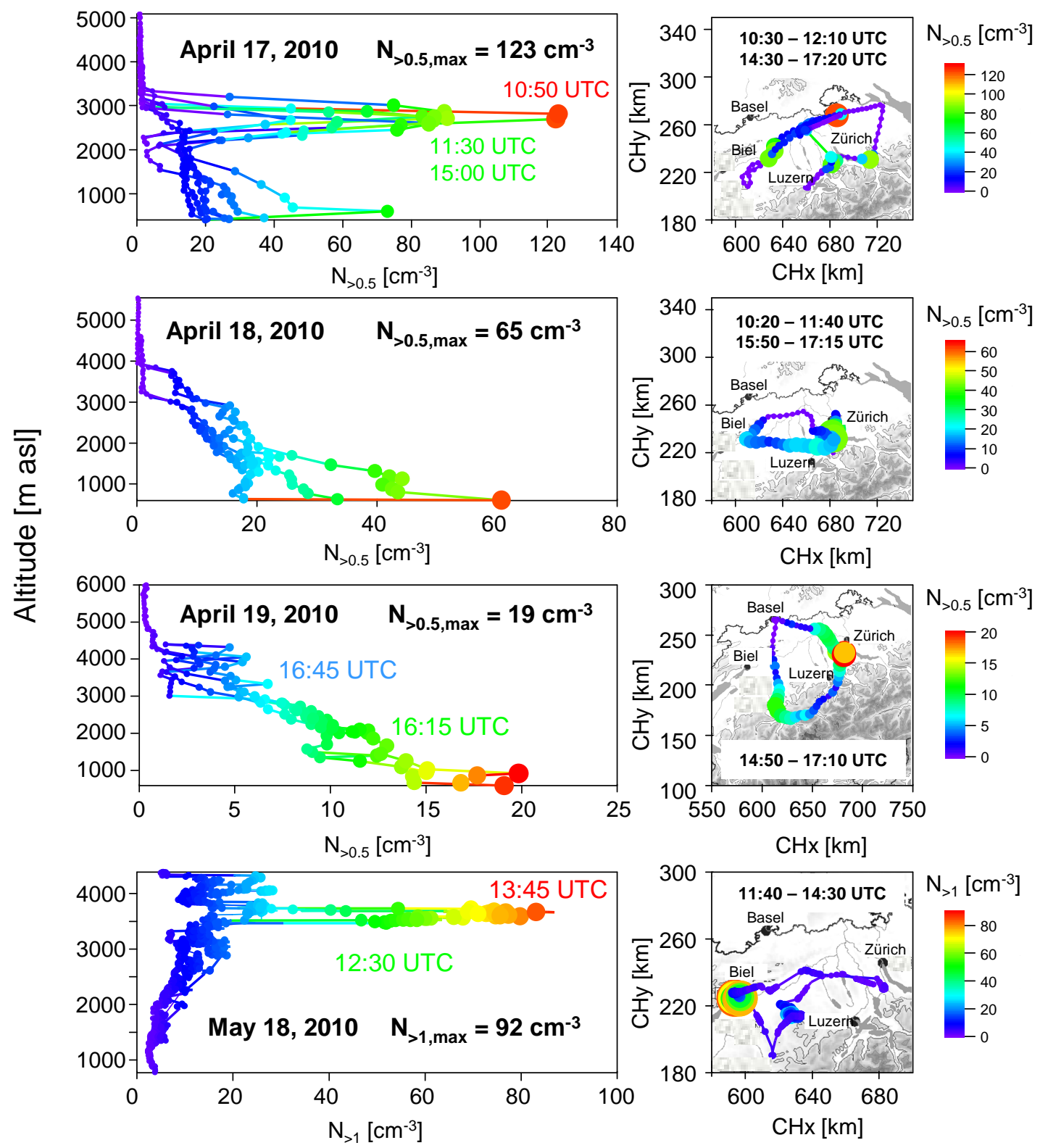

Fig. 11. In-flight number concentrations for particles with an optical diameter larger than $0.5 \mu \mathrm{m}\left(N_{>0.5}\right)$ or $1 \mu \mathrm{m}\left(N_{>1}\right)$, as a function of altitude (left panel) as well as geographical position and flight times (right panel). Data were corrected for sampling losses. $\mathrm{CHx}$ and $\mathrm{CHy}$ indicate the coordinates within the CH1903 coordinate system (TopoSwiss, 2010). The diameter size of the markers is proportional to the value of the displayed quantity. The Jungfraujoch is located South of the shown map domain.

(Northwestern Switzerland). Both the model result and the in-situ data show, along with further balloon soundings in Zürich and Payerne, that this subsequent plume did not reach the central Swiss plateau and the Alps but subsided over Southern Germany.

In May 2010 the in-situ measurements at the Jungfraujoch showed an arrival of the volcanic plume on 16 May (Fig. 1), while FLEXPART did not simulate the arrival of considerable amounts of volcanic ash on that same day. However, moderate amounts of ash were modeled to arrive from the North-West on 17 May, and the main peak observed on 18 May was only simulated for 19 May. The comparison suggests that there was a delay of about 6 to 12 hours in the simulations for the peak concentrations. Assuming that a similar delay was present in the simulations for 16 May, the conclusion that increased $\mathrm{PM}_{10}$ levels on 16 May were due to volcanic ash is also backed up by the simulations. 


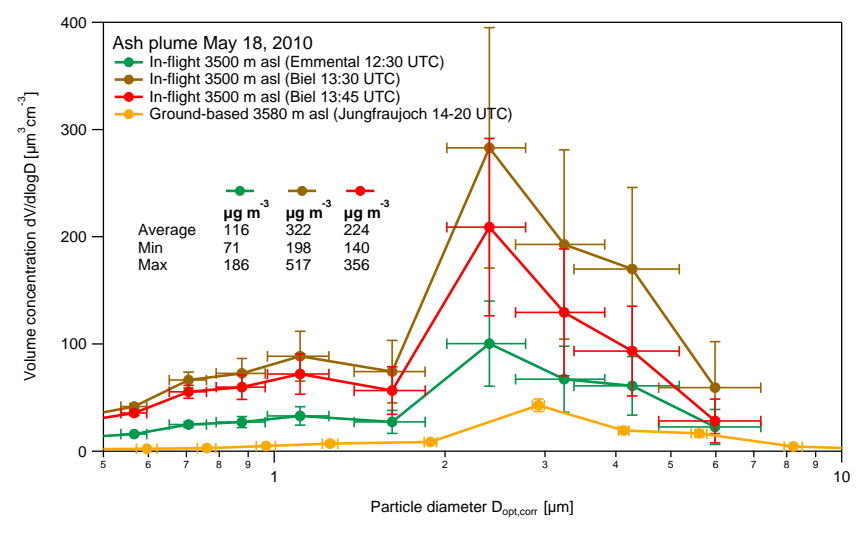

Fig. 12. In-flight volume distributions measured with the DIMO research aircraft over Switzerland on 18 May 2010, during periods with maximal ash concentrations. In addition, retrieved mass concentration are shown for coarse mode ash particles $\left(D_{\mathrm{opt}}>1 \mu \mathrm{m}\right)$, assuming a refractive index of $1.54+0.005 \mathrm{i}(\lambda=780 \mathrm{~nm})$ and a density of $2.65 \mathrm{~g} \mathrm{~cm}^{-3}$. For comparison, the maximal volume distribution measured at the Jungfraujoch on the same day is shown. Details on the applied diameter corrections for the two instruments are given in Appendix A1.

During the May episode, the in-situ and model data (Fig. 16) indicate the presence of a distinct layer over the Western Swiss plateau and the Alps, which was subsequently transported southwards by respective winds and reached Southern Switzerland on 19 May 2010. The northerly flow during this period caused a North-Föhn event which efficiently transported free tropospheric air from high altitudes above the Alpine crest into the boundary layer south of the Alps (Weber and Prévôt, 2002). Again, this layer was also captured by balloon soundings, which showed estimated ash mass concentrations of $50-100 \mathrm{\mu g} \mathrm{m}^{-3}$ at an altitude of 4000 m a.s.1. on 18 Mai 2010, 20:15 UTC. The FLEXPART simulation captured the Föhn related downward transport in the lee side of the Alps well with respect to peak concentrations and variability within Switzerland. However, the simulated peak South of the Alps lasted longer than the observed $\mathrm{PM}_{10}$ peak shown in Fig. 13 with its maximum following the observed maximum by about $18 \mathrm{~h}$.

In addition to the in-situ data presented here, several remote sensing measurements were performed in Switzerland applying Lidar instruments (light detection and ranging). The available but so far unpublished results (Engel et al., 2010; Simeonov et al., 2010) largely agree with the plume assessment using the in-situ and dispersion model results.

\section{Conclusions}

During the volcanic plume episodes in April and May 2010, a unique set of data was collected in Switzerland, which helps to complete the retrospective assessment of the volcanic ash burden of the airspace over Switzerland in April and May 2010. It includes data from high and low altitude in-situ measurements, as well as from research aircraft flights. The ground-based and airborne in-situ measurements as well as the modeling results described here show that the Jungfraujoch high Alpine research station was clearly influenced by the volcanic aerosol during two episodes in April and May, although the site did not encounter the same strong influence by volcanic aerosol as compared to other sites in Europe. Along with other mostly high Alpine or remote monitoring sites in Europe, the Jungfraujoch was one of the few places where a direct measurement of the ash mode mass concentration was achieved. The very extensive set of instruments running at the Jungfraujoch within the GAW and NABEL networks, complemented with the additionally collected aerosol and snow samples, allowed for a unique chemical and physical characterization of the volcanic aerosol. The observations at the Jungfraujoch were very consistent also with other observations made in Central Europe in terms of the chemical composition (Schleicher et al., 2011; Schumann et al., 2011; Schäfer et al., 2011), particle size distribution of the volcanic aerosol (Schäfer et al., 2011; Pitz et al., 2011) and new particle formation (Boulon et al., 2011). Dispersion models strongly benefit from this detailed information on the volcanic aerosol size distribution and its chemical composition. Given the fact that the volcanic plume was investigated several thousand kilometers downstream of the source, the agreement of the dispersion model results with the insitu data can be considered to be very good down to rather small spatial scales. Overall, the combination of continuous ground-based measurements within networks, selective airborne measurements and the support from modeling results represented a unique input for the decision makers. Future efforts should aim at finding combined strategies towards an online information system available during similar events.

The derivation of reliable mass concentrations for volcanic ash was difficult for optical particle counter measurements, due to the very strong influence of the aerosol optical and chemical properties on the size classification and subsequent conversion into a mass distribution. For use in aircraft, additional measurement uncertainties occur for supermicron particles even with an optimized system, because of the strong influence of the extreme sampling conditions on the isokinetic aerosol sampling. Despite these uncertainties, our research aircraft flights provided very important semiquantitative information on the prevailing ash load of the Swiss airspace in April 2010 and May 2010. The results of this paper illustrate that the in-flight determination of volcanic ash mass concentrations with both sufficient accuracy and precision for detecting the exceedance of the precisely defined legal threshold values is still very demanding, and can likely not be reasonably achieved with currently available instruments. Future work and strategies of the research community and decision makers should address this issue and improve quantitative measurements in future events. 

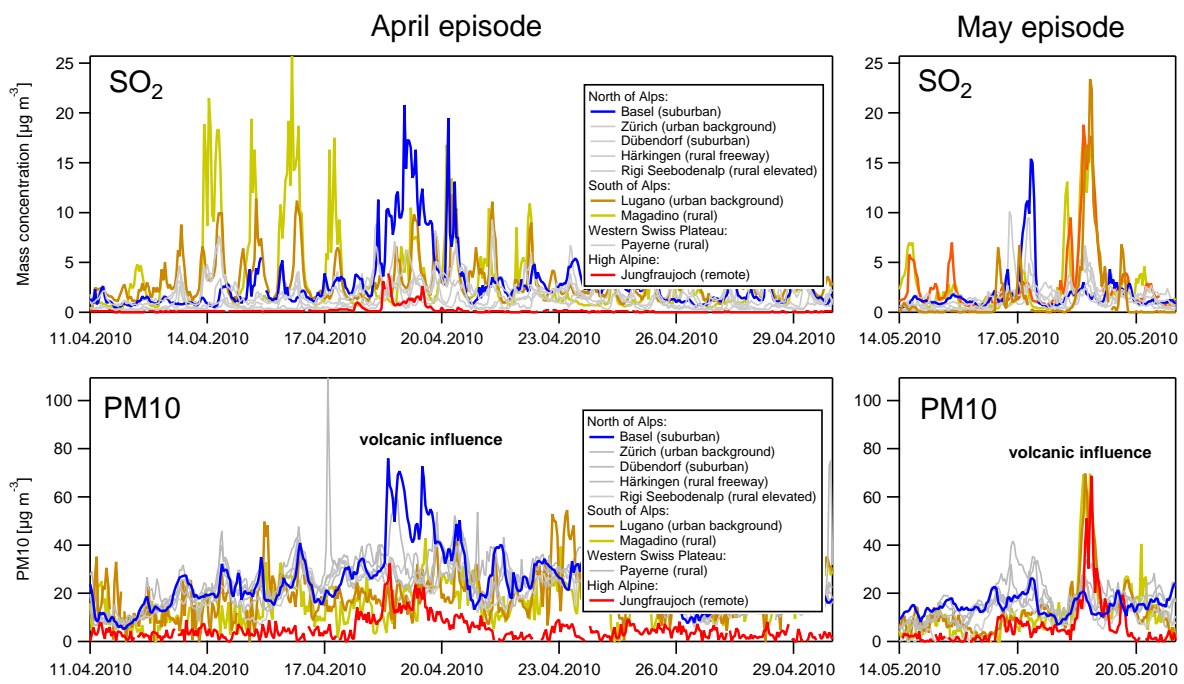

Fig. 13. April and May 2010: identification of stations with increased $\mathrm{PM}_{10}$ and $\mathrm{SO}_{2}$ concentrations within the Swiss Air Pollution Monitoring Network, indicating the presence of volcanic aerosol.
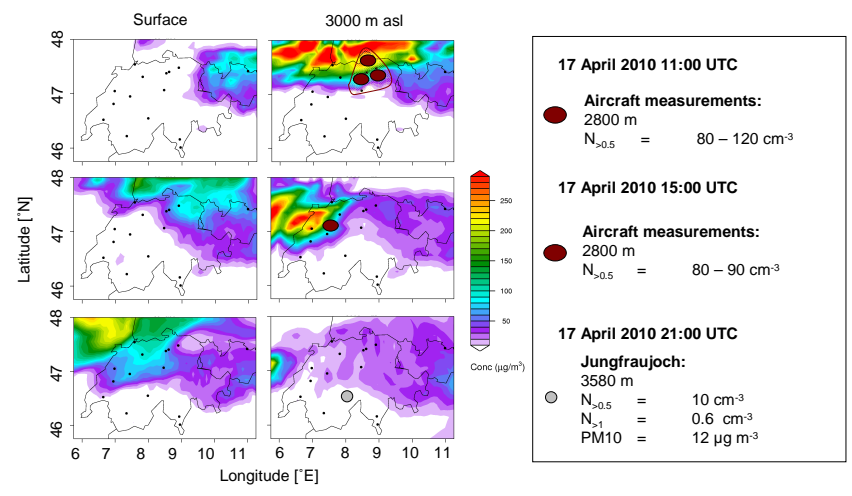

Fig. 14. 17 April 2010: comparison of the simulated volcanic ash concentration (surface and $3000 \mathrm{~m}$ a.s.l.) with the number and/or mass concentration values retrieved from the in-situ measurements.

\section{Appendix A}

\section{OPC corrections}

\section{A1 OPC diameter inversion using Mie calculations}

The Grimm 1.108 optical particle counters used in this study were factory-calibrated with monodisperse polystyrene latex spheres (PSL) in different sizes (Heim et al., 2008; Grimm $\mathrm{GmbH}$, personal communication, 2010) and had to be corrected for a proper sizing of volcanic ash particles. The data were inverted using Mie calculation, applying a Mie code based on the algorithm by Bohren and Huffman (2004). The scattering cross section was calculated with respect to the available technical details of the OPC (laser wavelength $780 \mathrm{~nm}$, opening angles $29.5-150.5^{\circ}$ and $81-99^{\circ}$,
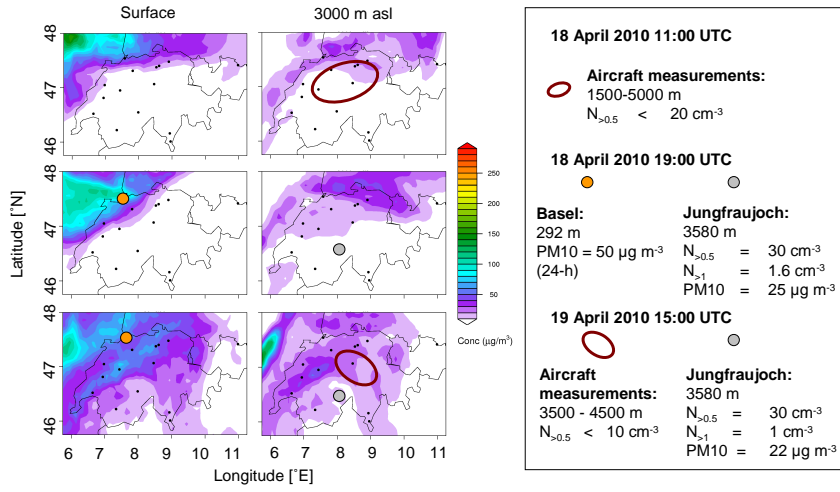

Fig. 15. 18/19 April 2010: comparison of the simulated volcanic ash concentration (surface and $3000 \mathrm{~m}$ a.s.l.) with the number and/or mass concentration values retrieved from the in-situ measurements.
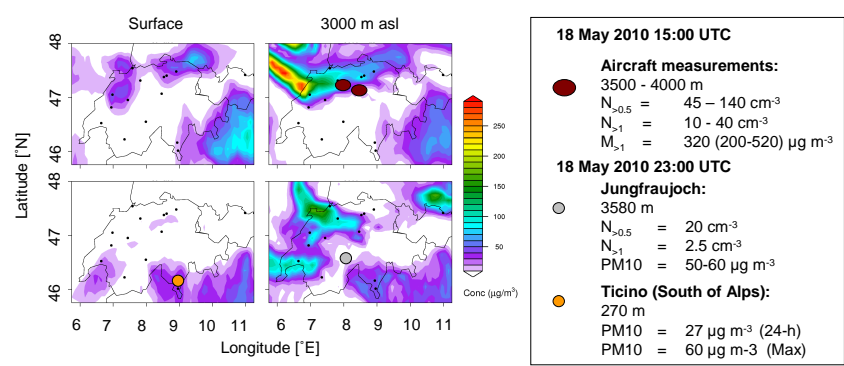

Fig. 16. 18 May 2010: comparison of the simulated volcanic ash concentration (surface and $3000 \mathrm{~m}$ a.s.l.) with the number and/or mass concentration values retrieved from the in-situ measurements. 


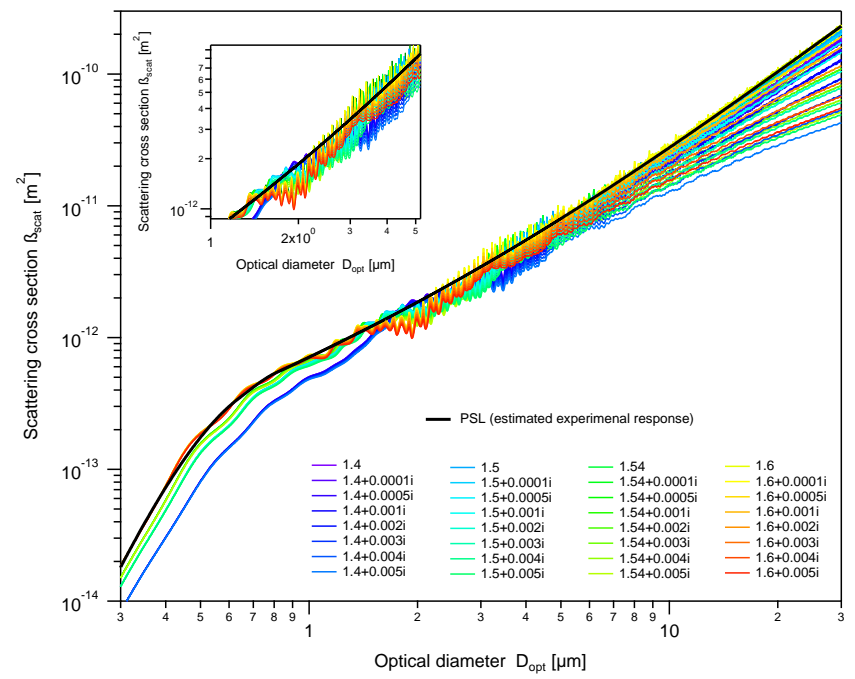

Fig. A1. Calculated scattering cross section versus the optical diameter for different refractive indices (see legend), considering the technical details of the used OPC (see text for details).

F. Schneider, Grimm GmbH, Germany, personal communication, 2010) for diameters up to $80 \mu \mathrm{m}$. The calculations did not take into account the non-sphericity of the particles and presupposed specific geometric details regarding the exact detector shape, which were not available from the manufacturer. The additional uncertainty introduced by these factors was however estimated to be relatively small, because the OPC diameter correction based on relative ratios of the scattering cross section curves. Figure A1 shows the Mie scattering cross sections for a selected matrix of refractive indices, varying the refractive index real part from 1.4 to 1.6 and the imaginary part from $0 \mathrm{i}$ to $0.005 \mathrm{i}$, respectively. These ranges include the values suggested in literature (Schumann et al., 2011; Peterson et al., 1969; Haynes, 2011; Volz, 1973) and thus are expected to include also the effective values for the volcanic ash found at the Jungfraujoch. The Mie wiggles and the plateau occurring between 1 and $3 \mu \mathrm{m}$ result in a non-monotonic function leading to a non bijective solution of the diameter correction (see example given in the inset of Fig. A2), and thus an increased correction uncertainty in this size range. Figure A3 shows the resulting correction curves for the selected refractive indices, which are based on the geometric mean diameter as described in Fig. A2. Because the experimental response curve was not available from the manufacturer, the presented correction curves are based on the smoothed theoretical scattering response curve for PSL (Fig. A1, green line). The smoothing mimics the effect of the uncertainties of an experimental calibration, namely the standard deviations of the applied monodisperse particles and the registered response voltages.

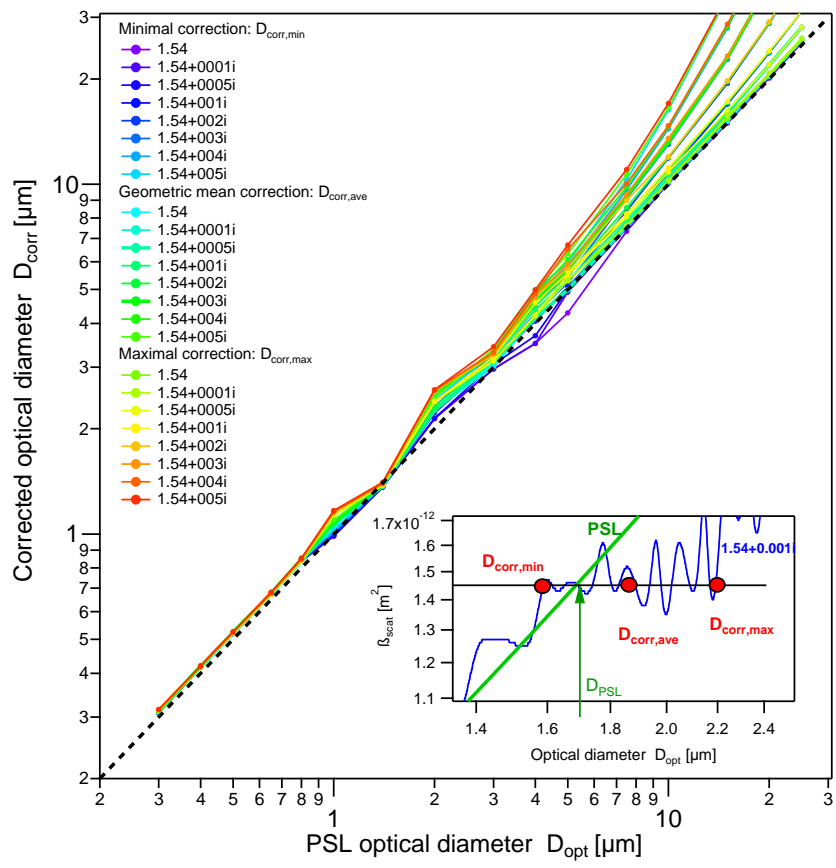

Fig. A2. OPC diameter correction curves for a complex refractive index with a fixed real part of 1.54 and an imaginary part ranging from 0i to $0.005 i$. Due to the wiggled and non-monotonic shape of the curves shown in Fig. A1, the diameter correction is not bijective. Therefore, minimal $\left(D_{\text {corr,min }}\right)$, geometric mean $\left(D_{\text {corr,ave }}\right)$ as well as maximal $\left(D_{\text {corr, } \max }\right)$ correction functions are shown (see illustration in the Figure inset).

To estimate realistic values for the refractive index of the volcanic aerosol detected at the Jungfraujoch, $\mathrm{PM}_{10}$ was calculated from the SMPS and OPC size distributions (see Sect. 3.1.3 for density assumptions) for all considered refractive indices and compared to directly measured $\mathrm{PM}_{10}$. Table A1 shows the slopes of the resulting linear correlation, as a measure for the agreement. The Table shows that the agreement is best for a real part between 1.5 and 1.6, and an imaginary part of $0.004 \mathrm{i}$ to $0.005 \mathrm{i}$ (and for the combination $1.4+0.002 \mathrm{i}$ ) for the given laser wavelength. Figure A4 shows the resulting volume size distributions measured during the first volcanic plume maximum on 17 April 2010. The resulting volume distribution based on a refractive index of $1.4+0.002 \mathrm{i}$ was considered as non realistic and was thus excluded from further consideration. The variation between the remaining volume size distributions reflects the methodological uncertainty of the OPC measurements and illustrates that the influence of the response curve plateau and the Mie wiggles is maximal exactly in the size range where the volcanic ash was detected. The shown uncertainties do not include the (unknown) experimental uncertainty of the PSL factory calibration curve.

The second Grimm 1.108, used on board of the aircraft, had previously been intercompared with the Grimm 
Table A1. Slopes of the linear correlation of $\mathrm{PM}_{10}$ directly measured at the Jungfraujoch (betagauge method, time window 17 April 2010, 18:00-19 April 2010, 12:00 UTC+1), versus PM $_{10}$ calculated from SMPS and OPC size distributions (see Sect. 3.1 .3 for density assumptions) for all considered refractive indices. Columns represent different real parts and rows different imaginary parts, respectively. Orthogonal distance regression was applied for the calculations. Due to the wiggled shape of the curves shown in Fig. A1, the diameter correction is not bijective for a given refractive index. Therefore, minimal (min), geometric mean (ave) as well as maximal (max) correction functions are shown as example.

\begin{tabular}{lllllll}
\hline & 1.40 & 1.50 & 1.60 & $1.54($ ave $)$ & $1.54(\min )$ & $1.54(\max )$ \\
\hline $0 \mathrm{i}$ & 0.89 & 0.75 & 0.66 & 0.71 & 0.64 & 0.76 \\
$0.0001 \mathrm{i}$ & 0.90 & 0.75 & 0.66 & 0.70 & 0.65 & 0.77 \\
$0.0005 \mathrm{i}$ & 0.89 & 0.77 & 0.67 & 0.72 & 0.65 & 0.77 \\
$0.001 \mathrm{i}$ & 0.91 & 0.77 & 0.68 & 0.72 & 0.69 & 0.79 \\
$0.002 \mathrm{i}$ & 0.97 & 0.78 & 0.69 & 0.75 & 0.70 & 0.89 \\
$0.003 \mathrm{i}$ & 1.02 & 0.87 & 0.69 & 0.86 & 0.76 & 0.91 \\
$0.004 \mathrm{i}$ & 1.06 & 0.92 & 0.79 & 0.86 & 0.82 & 0.93 \\
$0.005 \mathrm{i}$ & 1.19 & 0.96 & 0.81 & 0.87 & 0.85 & 0.95 \\
\hline
\end{tabular}

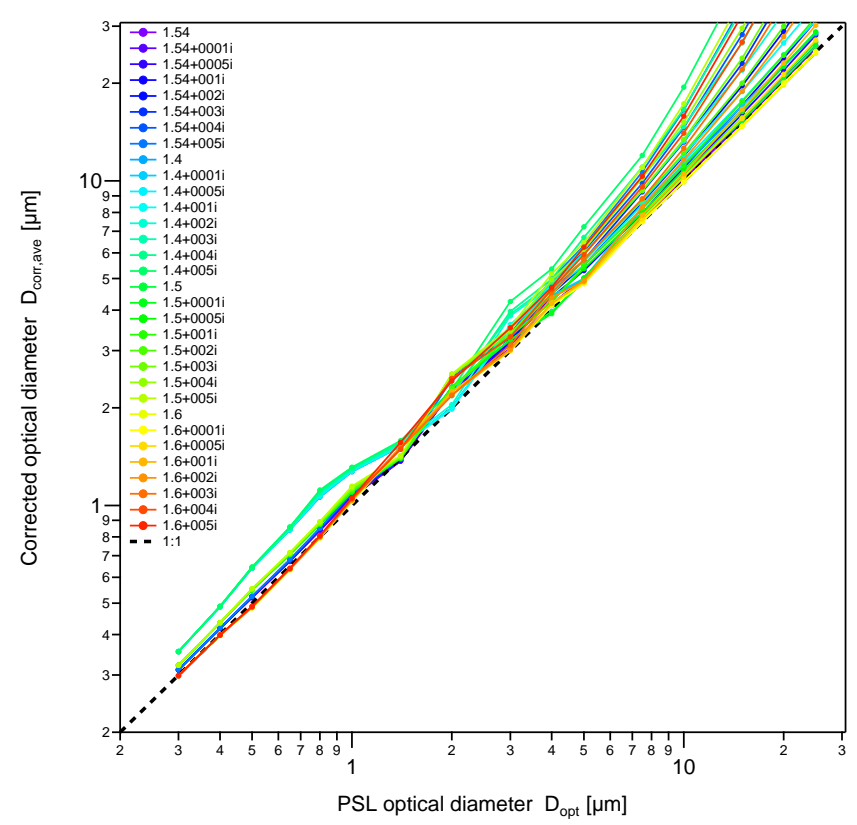

Fig. A3. Diameter correction curves for the deployed Grimm 1.108 OPC for a selected matrix of complex refractive indices.

1.108 used at the Jungfraujoch by parallel measurements during four months from December 2009 to March 2010. A significant difference was observed for the calibration of the instrument that was later used on board of the aircraft. This difference was empirically corrected by applying a size dependent correction factor to the nominal aircraft OPC diameters, to obtain identical volume size distributions. This empirical correction introduced considerable additional uncertainties to the measured in-flight size distributions, as shown in Fig. 12, Sect. 3.2.1.

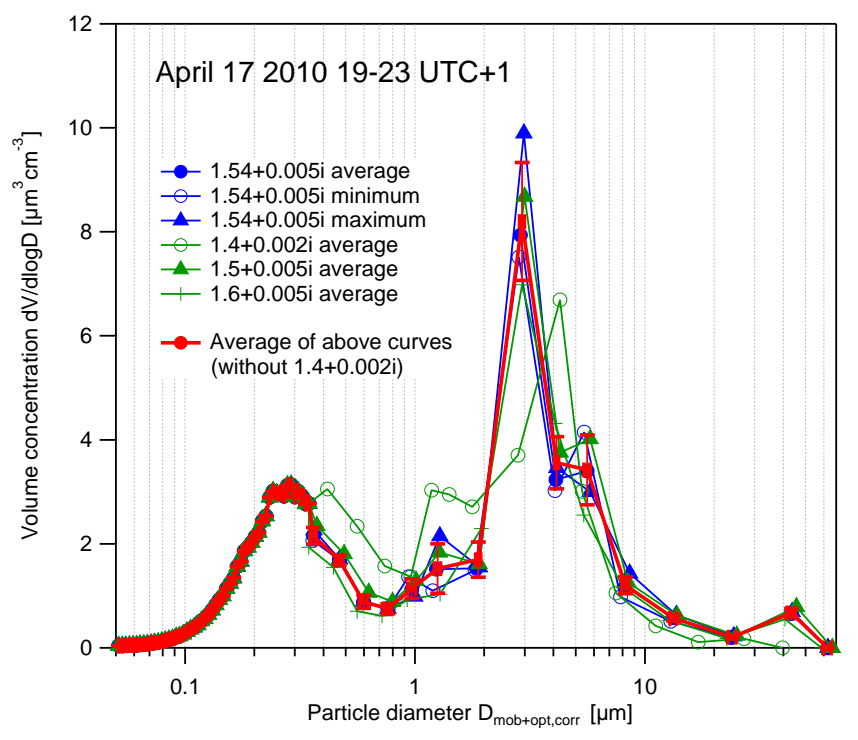

Fig. A4. Influence of the selected refractive index on the volume distribution measured at the Jungfraujoch during the first volcanic plume maximum in April. The shown average curve and standard deviation (red) does not include the unrealistic distribution obtained for $1.40+0.002 \mathrm{i}$.

\section{A2 OPC sampling loss corrections}

The use of the Grimm and MetOne particle counter onboard of the DIMO flights required an assessment of the particle size dependent sampling efficiency, which was strongly influenced by the deviation from ideally isokinetic sampling conditions. Table A2 lists the characteristics of the inlet pathways for the two optical counters. During two test flights (29 April 2010, no ash plume present), the operational volumetric flow of the two counters was monitored in-flight after the instrument outlet (TSI 4100, TSI Inc.), see Fig. A5. For the Grimm 1.108 there is a minor altitude dependence of the flow 
Table A2. Characteristics of the sampling lines for the optical counters used on board of the DIMO research aircraft.

\begin{tabular}{lll}
\hline Instrument & MetOne 4903 & Grimm 1.108 \\
\hline Isokinetic inlet tip diameter & $1.59 \mathrm{~mm}$ & $0.8 \mathrm{~mm}$ (inner diameter) stainless steel \\
Enlargement to & $1.59 \mathrm{~mm}$ & $4.4 \mathrm{~mm}$ (inner diameter) copper \\
Operational volumetric flow rate (see below) & $2.31 \mathrm{~min}^{-1}$ & $1.231 \mathrm{~min}^{-1}$ \\
Tube length & $0.2 \mathrm{~m}$ & $0.6 \mathrm{~m}$ \\
Angle of curvature & $90^{\circ}$ & $1.2^{\circ}$ \\
Isokinetic conditions at & $19.4 \mathrm{~m} \mathrm{~s}^{-1}\left(70 \mathrm{~km} \mathrm{~h}^{-1}\right)$ & $40.8 \mathrm{~m} \mathrm{~s}^{-1}\left(147 \mathrm{~km} \mathrm{~h}^{-1}\right)$ \\
\hline
\end{tabular}

rate, which is however largely within the noise of the measurements.

The in-flight sampling efficiency and transport losses were estimated using the particle loss calculator tool developed by the Max-Planck-Institute for Chemistry (MPI, von der Weiden et al., 2009) for all in-flight conditions (1-s intervals) and all size bins of the particle counters, assuming an aerosol density of $2.65 \mathrm{~g} \mathrm{~cm}^{-3}$ (volcanic ash). The calculated sampling efficiencies include the aspiration efficiency as well as eddy formation for super-isokinetic sampling. For the MetOne counter, the calculations were performed for an aerodynamic diameter $\left(D_{\mathrm{a}}\right)$ of $4 \mu \mathrm{m}$ for the $D_{\text {opt }}>0.5 \mu \mathrm{m}$ bin, since this corresponded to the observed mean aerodynamic diameter of the ash plume coarse mode in the volume distributions.

Figure A5 shows the influence of the true air speed, the inclination (misalignment) angle and the volumetric sample flow rate on the sampling efficiency (including the aspiration efficiency as well as eddy formation for super-isokinetic sampling, but without transport losses), calculated for $D_{\mathrm{a}}=$ $4 \mu \mathrm{m}$ and a particle density of $2.65 \mathrm{~g} \mathrm{~cm}^{-3}$. For larger particles the influence on the sampling efficiencies becomes even more pronounced. The sharp bend in some of the curves is due to different model calculation approaches above (Hangal and Willeke, 1990) and below (Liu et al., 1989) the isokinetic velocity ratio $U_{0} / U$. Sampling efficiencies larger than $100 \%$ indicate an enrichment of the particles in the sampling volume. The Grimm 1.108 showed disproportional losses in efficiency for sample flows larger than the standard operation flow rate $\left(1.231 \mathrm{~min}^{-1}\right)$ due to pronounced eddy formation at the inlet tip, plus further losses for misalignment angles larger than $3-4^{\circ}$ and for true air speeds below $40.8 \mathrm{~m} \mathrm{~s}^{-1}$. In contrast, the isokinetic air speed velocity was only $19.4 \mathrm{~m} \mathrm{~s}^{-1}$ for the MetOne. This value was always strongly exceeded except for take-off and landing, leading to a distinct oversampling of the particles. The misalignment was less critical for the MetOne setup compared to the Grimm 1.108 sampling system. Under the applied conditions, the estimated efficiencies partly exceed the recommended validity range of the underlying empirical relationships. The resulting efficiencies therefore have to be considered as estimates with an attached uncertainty. As a conservative approach for subsequent sampling loss correction,
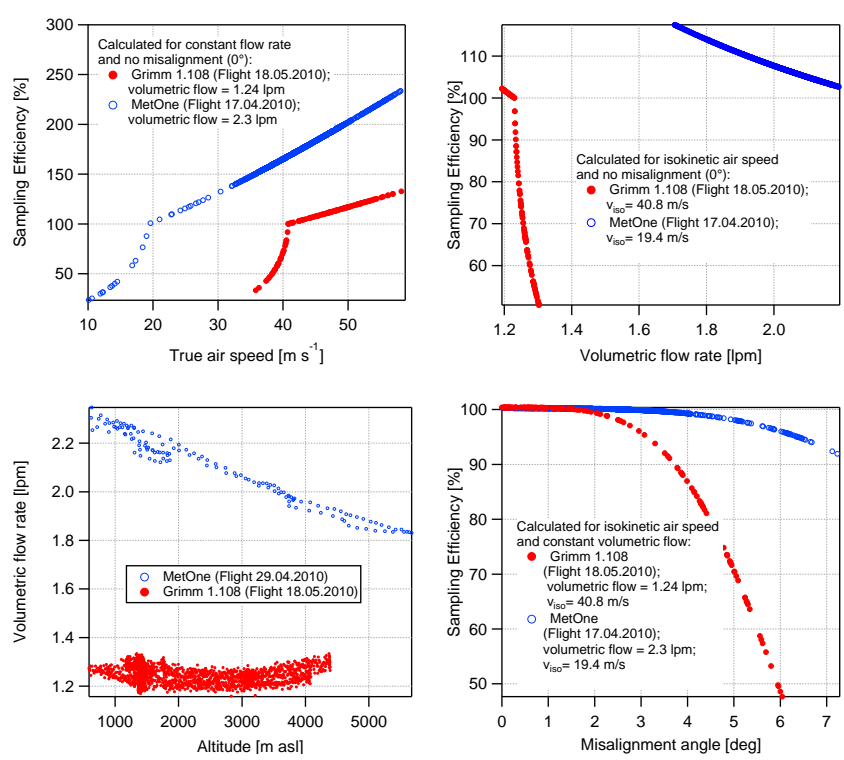

Fig. A5. Modeled sampling efficiency for $D_{\mathrm{a}}=4 \mu \mathrm{m}$ particles with a density of $2.65 \mathrm{~g} \mathrm{~cm}^{-3}$, as function of the true air speed, misalignment angle of the isokinetic sampling tip (Grimm OPC: inner diameter $0.8 \mathrm{~mm}$; MetOne OPC: inner diameter $1.59 \mathrm{~mm}$ ) and the volumetric flow rate, calculated for in-flight data measured by the two optical particle counters used on board of the DIMO research aircraft. The left bottom plot shows the measured altitude dependence of the volumetric instrument flow rate. The displayed sampling efficiencies include the aspiration efficiency as well as eddy formation for super-isokinetic sampling (von der Weiden et al., 2009).

size distributions which were subject to sampling efficiencies lower than $60 \%$ in the $D_{\mathrm{a}}=1-10 \mu \mathrm{m}$ range were not considered for analysis of the flight data, because the large correction factor for the usually very low number concentrations in this size range induced a too high propagated uncertainty for the corrected number concentration. For the inflight Grimm 1.108 data, only measurements with a true air speed $>41 \mathrm{~m} \mathrm{~s}^{-1}$, a misalignment angle $<2^{\circ}$ and a volumetric flow rate of $<1.281 \mathrm{~min}^{-1}$ were considered for analysis and corrected with the modeled sampling efficiency. These parameters were recorded every second during the flight. For the MetOne counter, the minimal acceptable true air speed 
was $20 \mathrm{~m} \mathrm{~s}^{-1}$, while changes in the other parameters did not lead to sampling efficiencies less than $60 \%$.

For the Grimm 1.108, the transport losses within the sampling line were estimated to be $15 \%$ for an aerodynamic diameter $D_{\mathrm{a}}$ of $3 \mu \mathrm{m}$ (assumed density $2.65 \mathrm{~g} \mathrm{~cm}^{-3}$ ) and $>60 \%$ for $D_{\mathrm{a}}>6 \mu \mathrm{m}$. The inlet sampling line for the MetOne counter included a strong bend, resulting from a compromise solution owing to space limitation during earlier projects and low priority of aerosol measurements. Due to this strong bend in the inlet line for the MetOne counter, there were significant transport losses $(>60 \%)$ already for particles larger than $D_{\mathrm{a}}>0.6 \mu \mathrm{m}$. To establish an empirical correlation between the number concentrations for $D_{\text {opt }}>$ $0.5 \mu \mathrm{m}\left(N_{>0.5}\right)$ measured with the MetOne and Grimm 1.108 counters, a technical flight was performed on 9 May 2010 (no clear ash layer present). Based on the results of this flight, the measured MetOne number concentrations could be empirically corrected for transport losses $\left(N_{>0.5}\right.$ (Grimm 1.108 , corrected for anisokinetic sampling and transport loss) $=3.4 \pm 2 \times N_{>0.5}$ (MetOne, corrected for anisokinetic sampling).

\section{Appendix B}

\section{List of abbreviations}

$\begin{array}{ll}\text { CCNC } & \text { Cloud condensation nuclei counter } \\ \text { CPC } & \text { Condensation particle counter } \\ \text { DIMO } & \text { Research aircraft (Diamond HK36 TTC-ECO) } \\ \text { EDX } & \text { Energy dispersive X-ray fluorescence spectrometry } \\ \text { FLEXPART } & \text { Lagrangian dispersion model } \\ \text { GAW } & \text { Global Atmosphere Watch Programme run } \\ & \text { by the World Meteorological Organization } \\ \text { IC } & \text { Ion chromatography } \\ \text { ICP-MS } & \text { Inductively coupled plasma mass spectrometry } \\ \text { NABEL } & \text { Swiss Air Quality Monitoring Network } \\ \text { OPC } & \text { Optical particle counter } \\ \text { PBL } & \text { Planetary boundary layer } \\ \text { PM } 10, \text { PM } & \text { Particulate matter with an aerodynamic } \\ \text { PSL } & \text { diameter smaller than 10 or 1 } \mu \text {, respectively } \\ \text { SEM } & \text { Polystyrene latex spheres } \\ \text { SMPS } & \text { Scanning electron microscopy } \\ \text { SS } & \text { Scanning mobility particle sizer } \\ \text { TSP } & \text { Supersaturation } \\ \text { VAAC } & \text { Total suspended particles } \\ & \text { Volcanic Ash Advisory Center }\end{array}$

Acknowledgements. This work was supported by MeteoSwiss within the Global Atmosphere Watch Programme of the World Meteorological Organization, the Swiss Federal Office for the Environment as part of the Swiss Air Quality Network (NABEL), the EC projects EUSAAR (contract no. 026140) and GEOmon (contract no. 036677), as well as the Swiss National Science Foundation. We thank the International Foundation High Altitude Research Stations Jungfraujoch and Gornergrat (HFSJG) for the opportunity to perform experiments on the Jungfraujoch. We are grateful to the custodians at the Jungfraujoch (Families Fischer and Seiler) for their inspection and maintenance of instrumentation. The ad-hoc flights, additional experimental and modeling activities were co-funded by the Swiss Office of Civil Aviation (FOCA), ETH, MeteoSwiss, Empa, Eawag and PSI. Additional Support for the flights was received by the ETH CCES project Maiolica. We also thank the DIMO pilots Dave Oldani and Moritz Isler for their efforts, Gonzague Romanens, Gilbert Levrat, and Rolf Philipona for balloon launches carried out from MeteoSwiss in Payerne, Sabina and Roland Brütsch (PSI) for the SEM analysis of the snow samples, and Johanna Spiegel for the discussions on Mie scattering.

Edited by: G. Pappalardo

\section{References}

Anderson, T., Covert, D., Marshall, S., Laucks, M., Charlson, R., Waggoner, A., Ogren, J., Caldow, R., Holm, R., Quant, F., Sem, G., Wiedensohler, A., Ahlquist, N., and Bates, T.: Performance characteristics of a high-sensitivity, three-wavelength, total scatter/backscatter nephelometer, J. Atmos. Ocean. Tech., 13, 967986, 1996.

Ansmann, A., Tesche, M., Gross, S., Freudenthaler, V., Seifert, P., Hiebsch, A., Schmidt, J., Wandinger, U., Mattis, I., Muller, D., and Wiegner, M.: The 16 April 2010 major volcanic ash plume over central Europe: EARLINET lidar and AERONET photometer observations at Leipzig and Munich, Germany, Geophys. Res. Lett., 37, L13810, doi:10.1029/2010GL043809, 2010.

Baltensperger, U., Schwikowski, M., Jost, D. T., Nyeki, S., Gäggeler, H. W., and Poulida, O.: Scavenging of atmospheric constituents in mixed phase clouds at the high-alpine site Jungfraujoch part I: Basic concept and aerosol scavenging by clouds, Atmos. Environ., 32, 3975-3983, 1998.

Blatt, H., Tracy, R. J., and Owens, B. E.: Petrology: Igneous, Sedimentary, and Metamorphic, W. H. Freeman Inc., 2006.

Bohren, C. and Huffmann, D.: Absorption and Scattering of Light by Small Particles, Wiley-VCH, New York, USA, 2004.

Boulon, J., Sellegri, K., Hervo, M., and Laj, P.: Observations of nucleation of new particles in a volcanic plume, P. Natl. Acad. Sci., 108, 12223-12226, doi:10.1073/pnas.1104923108, 2011.

Colette, A., Favez, O., Meleux, F., Chiappini, L., Haeffelin, M., Morille, Y., Malherbe, L., Papin, A., Bessagnet, B., Menut, L., Leoz, E., and Rouil, L.: Assessing in near real time the impact of the April 2010 Eyjafjallajökull ash plume on air quality, Atmos. Environ., 45, 1217-1221, 2011.

Collaud Coen, M., Weingartner, E., Schaub, D., Hueglin, C., Corrigan, C., Henning, S., Schwikowski, M., and Baltensperger, U.: Saharan dust events at the Jungfraujoch: detection by wavelength dependence of the single scattering albedo and first climatology analysis, Atmos. Chem. Phys., 4, 2465-2480, doi:10.5194/acp4-2465-2004, 2004.

Collaud Coen, M., Weingartner, E., Furger, M., Nyeki, S., Prévôt, A. S. H., Steinbacher, M., and Baltensperger, U.: Aerosol climatology and planetary boundary influence at the Jungfraujoch analyzed by synoptic weather types, Atmos. Chem. Phys., 11, 5931-5944, doi:10.5194/acp-11-5931-2011, 2011.

Cozic, J., Verheggen, B., Weingartner, E., Crosier, J., Bower, K. N., Flynn, M., Coe, H., Henning, S., Steinbacher, M., Henne, S., Collaud Coen, M., Petzold, A., and Baltensperger, U.: Chemical composition of free tropospheric aerosol for $\mathrm{PM}_{1}$ and coarse mode at the high alpine site Jungfraujoch, Atmos. Chem. Phys., 8, 407-423, doi:10.5194/acp-8-407-2008, 2008. 
Emeis, S., Forkel, R., Junkermann, W., Schäfer, K., Flentje, H., Gilge, S., Fricke, W., Wiegner, M., Freudenthaler, V., Groß, S., Ries, L., Meinhardt, F., Birmili, W., Münkel, C., Obleitner, F., and Suppan, P.: Measurement and simulation of the 16/17 April 2010 Eyjafjallajkull volcanic ash layer dispersion in the northern Alpine region, Atmos. Chem. Phys., 11, 2689-2701, doi:10.5194/acp-11-2689-2011, 2011.

Engel, I., Wienhold, F. G., Luo, B., Brabec, M., Cirisan, A., Krieger, U. K., Lolli, S., Baltensperger, U., Bukowiecki, N., Zieger, P., Meinhardt, F., Birmili, W., and Peter, T.: Eyjafjallajökull ash cloud observations above Zürich, International Aerosol Conference 2010, 29 August-3 September 2010, Helsinki, Finland, 2010.

EUFAR, European facility for airborne research, available at: http://www.eufar.net/wiki/pmwiki/pmwiki.php/EufarCMS/ VolcanicAshes?skin=view, last access: 10 February 2011, 2010.

EU (European Union), available at: http://ec.europa.eu/transport/ doc/2010_06_30_volcano_crisis_report.pdf, last access: February 2011,2010

Flentje, H., Claude, H., Elste, T., Gilge, S., Köhler, U., PlassDülmer, C., Steinbrecht, W., Thomas, W., Werner, A., and Fricke, W.: The Eyjafjallajökull eruption in April 2010 - detection of volcanic plume using in-situ measurements, ozone sondes and lidar-ceilometer profiles, Atmos. Chem. Phys., 10, 1008510092, doi:10.5194/acp-10-10085-2010, 2010.

Gasteiger, J., Groß, S., Freudenthaler, V., and Wiegner, M.: Volcanic ash from Iceland over Munich: mass concentration retrieved from ground-based remote sensing measurements, Atmos. Chem. Phys., 11, 2209-2223, doi:10.5194/acp-11-22092011, 2011.

Gudmundsson, M. T., Thordarson, T., Höskuldsson, A., Larsen, G., Jonsdottir, I., Oddsson, B., Magnusson, E., Högnadottir, T., Sverrisdottir, G., Oskarsson, N., Thorsteinsson, T., Vogfjörd, K., Björnsson, H., Pedersen, G. N., Jakobsdottir, S., Hjaltadottir, S., Roberts, M., Gudmundsson, G. B., Zophoniasson, S., and Höskuldsson, F.: The Eyjafjallajökull eruption in April-May 2010; course of events, ash generation and ash dispersal, presented at the AGU Annual Meeting, Friday 17 December 2010, San Francisco, USA, 2010.

Hangal, S. and Willeke, K.: Aspiration efficiency - unified model for all forward sampling angles, Environ. Sci. Technol., 24, 688$691,1990$.

Haynes, W. M. (Ed.): Density of various solids, in: CRC Handbook of Chemistry and Physics, 91st Edition (Internet Version 2011), CRC Press/Taylor and Francis, Boca Raton, FL, 2011.

Heim, M., Mullins, J. M., Umhauer, H., and Kasper, G.: Performance evaluation of three optical particle counters with an efficient multimodal calibration method, J. Aerosol Sci., 39, 10191031, 2008

Henne, S., Furger, M., Nyeki, S., Steinbacher, M., Neininger, B., de Wekker, S. F. J., Dommen, J., Spichtinger, N., Stohl, A., and Prévôt, A. S. H.: Quantification of topographic venting of boundary layer air to the free troposphere, Atmos. Chem. Phys., 4, 497509, doi:10.5194/acp-4-497-2004, 2004.

Henne, S., Brunner, D., Folini, D., Solberg, S., Klausen, J., and Buchmann, B.: Assessment of parameters describing representativeness of air quality in-situ measurement sites, Atmos. Chem. Phys., 10, 3561-3581, doi:10.5194/acp-10-3561-2010, 2010.

Heue, K.-P., Brenninkmeijer, C. A. M., Baker, A. K., Rauthe-
Schöch, A., Walter, D., Wagner, T., Hörmann, C., Sihler, H., Dix, B., Frieß, U., Platt, U., Martinsson, B. G., van Velthoven, P. F. J., Zahn, A., and Ebinghaus, R.: $\mathrm{SO}_{2}$ and $\mathrm{BrO}$ observation in the plume of the Eyjafjallajökull volcano 2010: CARIBIC and GOME-2 retrievals, Atmos. Chem. Phys., 11, 2973-2989, doi:10.5194/acp-11-2973-2011, 2011.

IATA, International Air Transport Association, available at: http://www.iata.org/whatwedo/Documents/economics/ Volcanic-Ash-Plume-May2010.pdf, last access: 10 February 2011, 2010.

Jurányi, Z., Gysel, M., Weingartner, E., Bukowiecki, N., Kammermann, L. and Baltensperger, U.: 17-month climatology of the cloud condensation nuclei number concentration at the high alpine site Jungfraujoch, J. Geophys. Res. Atmos., 116, D10204, doi:10.1029/2010JD015199, 2011.

Lettino, A., Caggiano, R., Fiore, S., Macchiato, M., Sabia, S., and Trippetta, S.: Eyjafjallajökull volcanic ash in southern Italy, Atmospheric Environment, doi:10.1016/j.atmosenv.2011.05.037, in press, 2011.

Liu, B. Y. H., Zhang, Z. Q., and Kuehn, T. H.: A numerical study of inertial errors in anisokinetic sampling, J. Aerosol Sci., 20, 367-380, 1989.

Mona, L., Amodeo, A., D’Amico, G., Giunta, A., Madonna, F., and Pappalardo, G.: Multi-wavelength Raman lidar observations of the Eyjafjallajökull volcanic cloud over Potenza, Southern Italy, Atmos. Chem. Phys. Discuss., 11, 12763-12803, doi:10.5194/acpd-11-12763-2011, 2011.

Neininger, B., Fuchs, W., and Baeumle, M.: A small aircraft for more than just ozone: Metair's 'Dimona' after ten years of evolving development, in: 11th Symposium on Meteorological Observations and Instrumentation, Amer. Met. Soc., Boston, 123-128, 2001.

Nyeki, S., Baltensperger, U., Colbeck, I., Jost, D. T., Weingartner, W., and Gäggeler, H. W: The Jungfraujoch high-alpine research station $(3454 \mathrm{~m})$ as a background continental site for the measurement of aerosol parameters, J. Geophys. Res., 103, 60976107, 1998.

Peterson, J. T. and Weinman, J. A.: Optical Properties of Quartz Dust Particles at Infrared Wavelengths, J. Geophys. Res., 74, 6947-6952, doi:10.1029/JC074i028p06947, 1969.

Petters, M. D. and Kreidenweis, S. M.: A single parameter representation of hygroscopic growth and cloud condensation nucleus activity, Atmos. Chem. Phys., 7, 1961-1971, doi:10.5194/acp-71961-2007, 2007.

Petters, M. D., C. M. Carrico, S. M. Kreidenweis, A. J. Prenni, P. J. DeMott, J. L. Collett Jr., and Moosmüller, H.: Cloud condensation nucleation activity of biomass burning aerosol, J. Geophys. Res., 114, D22205, doi:10.1029/2009JD012353, 2010.

Pitz, M., Gu, J., Soentgen, J., Peters, A., and Cyrys, J.: Particle size distribution factor as an indicator for the impact of the Eyjafjallajökull ash plume at ground level in Augsburg, Germany, Atmos. Chem. Phys. Discuss., 11, 16417-16437, doi:10.5194/acpd-11-16417-2011, 2011.

Rauthe-Schöch, A., Weigelt, A., Hermann, M., Martinsson, B. G., Baker, A. K., Heue, K.-P., Brenninkmeijer, C. A. M., Zahn, A., Scharffe, D., Eckhardt, S., Stohl, A., and van Velthoven, P. F. J.: CARIBIC aircraft measurements of Eyjafjallajökull volcanic plumes in April/May 2010, Atmos. Chem. Phys. Discuss., 11, 16693-16744, doi:10.5194/acpd-11-16693-2011, 2011. 
Rossini, P., Molinaroli, E., De Falco, G., Fiesoletti, F., Papa, S., Pari, E., Renzulli, A., Tentoni, P., Testoni, A., Valentini, L., and Matteucci, G.: April-May 2010 Eyjafjallajökull volcanic fallout over Rimini, Italy, Atmospheric Environment, doi:10.1016/j.atmosenv.2011.05.018, in press, 2011.

Schäfer, K., Thomas, W., Peters, A., Ries, L., Obleitner, F., Schnelle-Kreis, J., Birmili, W., Diemer, J., Fricke, W., Junkermann, W., Pitz, M., Emeis, S., Forkel, R., Suppan, P., Flentje, H., Wichmann, H. E., Gilge, S., Meinhardt, F., Zimmermann, R., Weinhold, K., Soentgen, J., Münkel, C., Freuer, C., and Cyrys, J.: Influences of the 2010 Eyjafjallajkull volcanic plume on air quality in the northern Alpine region, Atmos. Chem. Phys. Discuss., 11, 9083-9132, doi:10.5194/acpd-11-9083-2011, 2011.

Schleicher, N., Kramar, U., Dietze, V., Kaminski, U., and Norra, S.: Geochemical characterization of single atmospheric particles from the Eyjafjallajökull volcano eruption event collected at ground-based sampling sites in Germany, Atmos. Environ., doi:10.1016/j.atmosenv.2011.05.034, in press, 2011.

Schumann, U., Weinzierl, B., Reitebuch, O., Schlager, H., Minikin, A., Forster, C., Baumann, R., Sailer, T., Graf, K., Mannstein, H., Voigt, C., Rahm, S., Simmet, R., Scheibe, M., Lichtenstern, M., Stock, P., Rüba, H., Schäuble, D., Tafferner, A., Rautenhaus, M., Gerz, T., Ziereis, H., Krautstrunk, M., Mallaun, C., Gayet, J.-F., Lieke, K., Kandler, K., Ebert, M., Weinbruch, S., Stohl, A., Gasteiger, J., Groß, S., Freudenthaler, V., Wiegner, M., Ansmann, A., Tesche, M., Olafsson, H., and Sturm, K.: Airborne observations of the Eyjafjalla volcano ash cloud over Europe during air space closure in April and May 2010, Atmos. Chem. Phys., 11, 2245-2279, doi:10.5194/acp-11-2245-2011, 2011.

Sigmundsson, F., Hreinsdottir, S., Hooper, A., Arnadottir, T., Pedersen, R., Roberts, M. J., Oskarsson, N., Auriac, A., Decriem, J., Einarsson, P., Geirsson, H., Hensch, M., Ofeigsson, B. G., Sturkell, E., Sveinbjornsson, H., and Feigl, K. L.: Intrusion triggering of the 2010 Eyjafjallajokull explosive eruption, Nature, 468, 426-430, 2010.

Simeonov, V., Dinoev, T., Parlange, M., Serikov,I., Calpini, B., Wienhold, F., Engel, I., Brabec, M., Cirisan, A., Peter, T., Mitev, V., and Matthey R.: Lidar observation of Eyjafjallajoekull ash layer evolution above the Swiss Plateau, International Aerosol Conference 2010, 29 August-3 September 2010, Helsinki, Finland, 2010.

Stohl, A., Forster, C., Frank, A., Seibert, P., and Wotawa, G.: Technical note: The Lagrangian particle dispersion model FLEXPART version 6.2, Atmos. Chem. Phys., 5, 2461-2474, doi:10.5194/acp-5-2461-2005, 2005.

Stohl, A., Prata, A. J., Eckhardt, S., Clarisse, L., Durant, A., Henne, S., Kristiansen, N. I., Minikin, A., Schumann, U., Seibert, P., Stebel, K., Thomas, H. E., Thorsteinsson, T., Tørseth, K., and Weinzierl, B.: Determination of time- and height-resolved volcanic ash emissions and their use for quantitative ash dispersion modeling: the 2010 Eyjafjallajökull eruption, Atmos. Chem. Phys., 11, 4333-4351, doi:10.5194/acp-11-4333-2011, 2011. swisstopo, Swiss Federal Office of Topography, available at: http://www.swisstopo.admin.ch/internet/swisstopo/en/home/ topics/survey/sys/refsys/projections.html, last access: 10 February $2011,2010$.

Volz, F. E.: Infrared optical constants of ammonium sulfate, Sahara dust, volcanic pumice and fly ash, Appl. Opt., 12, 564-568,1973.

von der Weiden, S.-L., Drewnick, F., and Borrmann, S.: Particle Loss Calculator - a new software tool for the assessment of the performance of aerosol inlet systems, Atmos. Meas. Tech., 2, 479-494, doi:10.5194/amt-2-479-2009, 2009.

Weber, K., Vogel, A., Fischer, C., van Haren, G., and Pohl, G.: Airborne measurements of the Eyjafjallajkull volcanic ash plume over northwestern Germany with a light aircraft and an optical particle counter: first results, in: Lidar Technologies, Techniques, and Measurements for Atmospheric Remote Sensing VI, edited by: Singh, N. and Pappalardo, G., Proc. SPIE, 7832, doi:10.1117/12.869629, 2010.

Weber, R. O. and Prévôt, A. S. H.: Climatology of ozone transport from the free troposphere into the boundary layer south of the Alps during North Foehn, J. Geophys. Res., 107, 4030, doi:10.1029/2001JD000987, 2002.

Weingartner, E., Nyeki, S., and Baltensperger, U.: Seasonal and diurnal variation of aerosol size distributions $(10<D<750 \mathrm{~nm})$ at a high-alpine site (Jungfraujoch $3580 \mathrm{~m}$ asl), J. Geophys. Res. Atmos., 104, 26809-26820, 1999.

Wiedensohler, A., Birmili, W., Nowak, A., Sonntag, A., Weinhold, K., Merkel, M., Wehner, B., Tuch, T., Pfeifer, S., Fiebig, M., Fjäraa, A. M., Asmi, E., Sellegri, K., Depuy, R., Venzac, H., Villani, P., Laj, P., Aalto, P., Ogren, J. A., Swietlicki, E., Roldin, P., Williams, P., Quincey, P., Hüglin, C., Fierz-Schmidhauser, R., Gysel, M., Weingartner, E., Riccobono, F., Santos, S., Grüning, C., Faloon, K., Beddows, D., Harrison, R. M., Monahan, C., Jennings, S. G., O’Dowd, C. D., Marinoni, A., Horn, H.-G., Keck, L., Jiang, J., Scheckman, J., McMurry, P. H., Deng, Z., Zhao, C. S., Moerman, M., Henzing, B., and de Leeuw, G.: Particle mobility size spectrometers: harmonization of technical standards and data structure to facilitate high quality long-term observations of atmospheric particle number size distributions, Atmos. Meas. Tech. Discuss., 3, 5521-5587, doi:10.5194/amtd-3-55212010, 2010.

Zellweger, C., Forrer, J., Hofer, P., Nyeki, S., Schwarzenbach, B., Weingartner, E., Ammann, M., and Baltensperger, U.: Partitioning of reactive nitrogen $\left(\mathrm{NO}_{\mathrm{y}}\right)$ and dependence on meteorological conditions in the lower free troposphere, Atmos. Chem. Phys., 3, 779-796, doi:10.5194/acp-3-779-2003, 2003.

Zieger, P., Fierz-Schmidhauser, R., Gysel, M., Ström, J., Henne, S., Yttri, K. E., Baltensperger, U., and Weingartner, E.: Effects of relative humidity on aerosol light scattering in the Arctic, Atmos. Chem. Phys., 10, 3875-3890, doi:10.5194/acp-10-38752010, 2010. 